C77 



\section{COONS' TREATISE}

ON

\section{FARM, PRAIRIE, FLOOD, HURDLE}

\section{AND \\ ORNAMENTAL FENCES, \&C. \\ ALsO A}

FULL DESORIPTION OF COONS' PATENT FLEXIBLE FENCES, RAILING, \&C., WHICH ARE MANUFACTURED AT THE UNITED STATES FENCE WORKS, STATE DAM, TROY, N. Y.,

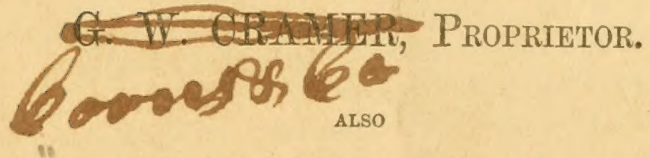

\section{A SCALE OF PRICES ATTACHED,}

FOR EACH AND EVERY GRADE OF FENCE, \&C.,

ILUSTRATED WITH WOOD CUTS,

REPRESENTING A FEW

OF THE MANY DESIGNS MANUFACTURED AT THIS ESTABLISHMENT.

$\checkmark$ TROY, N. Y.

1. G. JOHNSON, STEAM PRESS PRINTER, $\nabla$ CANXON PLAOE. 


$$
{ }^{572^{5}} \mathrm{C}^{77}
$$




\section{PREFACE.}

Tо тне Puвlic.-On introducing a brief treatise on Farm and Ornamental Fences, to an enlightened and reading people, may by some be considered as of little importance, as almost every person interested upon the subject, has his own views and opinions, and those opinions based upon some theory or practical tests, and that a word upon this subject will make but a light impression upon the public mind. But, having made this my business for the last six years, and during that time have not only been a close observer, but also, examined all the various plans, designs and improvements in the principles of constructing fences in many parts of the United States, and have, also, made many experiments and practical tests, \&c., all for the purpose of obtaining information upon a subject interesting to me as well as the country at large, and finally came to the conclusion, that in all cases, cast iron posts could be substituted for wood posts; and finally, after progressing step by step, have come to the conclusion that not only iron fence posts can and may be generally adopted, but that all classes of farm, as well as ornamental fences made wholly of iron, may, and eventually will be adopted in every part of the United States where there is any relative value attached to timber. After having introduced my system to a limited extent, I was called upon frequently to answer interrogatories relative thereto, and finally was requested to make public my views. After having made arrangements with George W. Cramer, of the eity of Troy, to manufacture all the various styles and varieties of my plans of Farm and Ornamental fence, and he having made extensive arrangements and is now manufacturing to order, all the varieties, I have thought proper to take this method of extending to the public such information as I may possess, and append a few of the many testimopials which I have received; and, also, append explanations and wood cuts of a ferw of the many designs and styles of Fence manufactured at the United States Patent Fence Works, Troy, N. Y.

MATTHIAS P. COONS. 


\section{RECOMMENDATIONS.}

Letter from Col. B. P. Jounson, Secretary of the N. Y. State Agricultural Society, and of George Vail, Risq., President.

Mr. M. P. Coons,

State Agricultural Rooms,

Albany, May 13, 1852.

Dear Sir:-I have read the manuscript of your "Treatise on Farm and Ornamental Fencing," and am pleased with the suggestions contained in it. The subject is one of great interest to the Farmers of our country, and I am satisfied from an examination of your improvements that they will prove of great value, and worthy the attention of all who are interested in the subject.

Yours,

B. P. JOHNSON, Secretary.

I concur in the views and opinions expressed above by Col. B. P. Johnson.

GEO. VAIL.

From Wм. H. StaRr, Esq., late Editor Farmer and Mechanic, New York.

M. P. Coons, Esq,

NeW YoRK, June 15, 1852.

Dear Sir:-Having been for some years past somewhat acquainted with your experiments, and valuable improvements in farm and ornamental fencive. I have been induced to give the subject a good degree of attention, and cannot but cordially commend your various improvements to public notice, and public patronage.

Your "treatise," (in manuscript) which you were so obligi as to place in my hands for perusal gives the whole subject new interest, and its suggestions are valuable as contributing very much to that fund of information which the farmers, especially of country, need in regard to the matter. 
You have my best wishes for the success of your enterprise, in furnishing cheap and improved methods of fencing, both durable and ornamental wherein the article is required.

Respectfully yours,

WM. H. STARR.

From Hon. A. Van Tuyl, Treasurer of Rensselaer Ag'l. Society.

M. P. Coons, Esq.

Trox, June 1st, 1852.

Dear Sir :-Your manuscript "Treatise on Iron and Ornamental Fencing," placed in my hands, I have perused with some care and much pleasure. You will do good service to the public by publishing and spreading your views, broadeast, throughout this and other States. The suggestions therein contained will be approved by those interested in erecting both ornamental and durable farm fence. Yours truly,

A. VAN TUYL.

From Henry Warren, Esq., Agricultural Warehouse, Troy.

M. P. Coons,

Troy, June 7, 1852.

Dear Sir:-Having occasionally, for sometime past, noticed various specimens of your new and improved style of farm and ornamental fencing, it gives me pleasure to say that $\mathrm{I}$ consider them unsurpassed in taste, in economy, and beauty of design. Having given your manuscript treatise on this subject a cursory perusal, I feel confident you will receive a hearty approval from those to whom it is addressed.

Yours truly,

H. WARREN.

From Hon. Jонn C. Mather, Canal Commissioner of the State of New-York.

M. P. Coons, Esq.

Trox, July 22d, 1852.

Dear Sir:-I have examined, with much interest, a copy, in manuscript, of your "Treatise on Farm and Ornamental Fencing." It contains many valuable suggestions on the subject of which it treats, and cannot fail of being read, with interest by every farmer in the country. Your great experience and skill in the manufacture of fencing, of various kinds, has always very justly given you a wide-spread reputation as an inventor of, perhaps, the best style of fence ever brought before the public. I trust you will meet with the success you deserve at the hands of those most deeply interested in the matter.

With great respect, yours truly, 


\title{
RESPECTFULLY DEDICATED
}

\author{
TO THE
}

\section{N. Y. STATE AGRICULTURAL SOCIETY.}

The undersigned would most respectfully state that his time and attention has been almost wholly deroted to the improvement of farm and ornamental fences, endeavoring to mitigate the many difficulties, and also the heavy expense now incurred by the various plans generally adopted in this and adjoining States.

Having been a practical farmer of Rensselaer county for upwards of twenty years, he embraced every opportunity of detecting every error which he could detect, and then endeavored to devise some means whereby the many difficulties could be mitigated or removed and consequently resorted to many practical tests and experiments.

There were several important facts which presented themselves for consideration, many of which were of much importance, and should require the particular attention of all interested upon the subject and may be classed as follows, particularly farm fencing.

1st. The rapid decrease of timber aud the consequent high prices demanded for materials.

2. The extreme perishable nature of the materials used in the construction of farm fences.

3. The time and labor expended in the construction.

4. The space occupied by most of the varieties now used.

5 . The difficulties encountered in the erection of fences secured by wood posts placed perpendicularly in the ground, and which are subject to the following objections: First, the effects of frost, the posts raising upwards; second, by wind in two important particulars, one is the liability of the prostration of the structure, and the others are as follows:- It is well known by experience that nearly all fences made of wood or stone wall, are sufficiently compact to create a vacuum in the atmosphere in proportion to the density of the structure, in which large masses of drifting snow is permited to accumulate, forced thither by the "driving storm."

6 . The present difficulties encountered in fencing all lands subject to inundation and system of "hurdle fencing."

7. The fragil "cob web" wood post wire fences.

8. The expense now incurred by enclosing the Western Prairies. 
9. The great expense now incurred in fencing railroads, highways \&c., ard the rapid dilapidation, and consequent danger to life and property.

All the above difficulties and objections have each been the subject of due consideration and reflection, and each in their respective capacity have been a theme of mental labor and practical tests, no one particular part was permitted to pass without such experiments being made, sufficient to satisfactorily demonstrate the position hereafter assumed. Several articles of fence which was adopted by our fore-fathers when they were the Pioneers of the primeval Forests, need not now be considered as they have long since disappeared.

\section{LOG FENCES}

Can only be seen in new countries, and in many instances (like stone in some localities) are made into fence to get timber " out of the way ;" and as the propriety of discussing their merits or demerits is considered useless, therefore, pass them over.

\section{WORM RAIL FENCES.}

This style of fence was adapted as the $2 \mathrm{~d}$ class or plan of enclosing farms, \&c., and was in many instances the most feasible plan that then could be adopted, and was also a fruitful source of getting rid of the surplus timber; and as they have become almost extinct, and in many sections of our country are now among the things that were, it is, therefore, considered unnecessary to go into a detail of the many objections to this suicidal course of exterminating timber. Many hedges and poisonous beds of weeds have disappeared, to which worm rail fences once gave protection and shelter.

This class of fence having been most generally adopted throughout our country, and by the rapid decay and the continued renewal may be justly considered as the prominent cause of the spare and languid appearance of our forests. By computations made in 1848, by competent persons, it was estimated that about three millions of cords of timber was annually taken from our forests, for fencing purposes, in the State of New York. What old resident farmer in this part of the State, does not recollect that in "by gone days" did not wholly rely upon the accumulation of old fences for his summer's firewood.

Nature having put a "veto" upon the further progress of this system of annihilating timber, it is therefore unnecessary to pursue this subject any further.

\section{POST AND RAIL FENCES.}

This plan was considered an improvement upon the worm rail fence, as it required less material, and was considered a more permanent structure, not the sport of every breeze, nor the protector of the noxious shrubs and plants; and as this class of fence is subject to the same class of objections as that of the post and board fence, we will there leave it for a further analysis. 


\section{POST AND BOARD FENCES.}

This class of fence has now been almost universally adopted in all localities, wherever forests have been exhausted by the continual demand made upon them for the extravagant supply required for the various purposes, and particularly on account of the rapid decay of fence materials.

This plan may be justly considered an improvement upon farm fencing, on those named, yet notwithstanding, there are many objections to this system, and on some classes of soil wholly impracticable, and in fact there are but few classes of soil upon which post and board fence can be considered, in any degree, as permanent, and those also are subject to various objections.

A wood post set in clay soils, or clay loam, or loam, is not subject to as rapid decay as in sand, sandy loam, or gravelly soils. In the first, the post is subject to be raised by the effects of the frost, or as it is more generally termed, it "freezes out," and to replace the post to its former position, if boards are nailed thereon, it is nearly equivalent to rebuilding the fence. Various methods have been tried, and even letters patent have been issued, purporting to be devised to overcome these difficulties, but none of which appears to have been effectual, as they seem not to have become in general use. Nature appears to have placed a barrier in the way to this plan of setting posts, in all northern climates ; and if some of the devises had been effectual in remedying the difficulty in part, of the raising of the post by frost, it did not overeome many other difficulties. Admitting that an invention was effeetual in preventing a post from heaving, then all the following objections are yet prominent, and not removed or mitigated.

1. The cost of a post and board fence is, in many parts of our common country, a heavy tax, if not a perfect barrier to its adoption.

2. When it is built, it is of wood, and extremely perishable.

3 . It is, out of doors, subject to the elements, and the rapid decay and destruction consequent thereto.

4. It is the fruitful means of large accumulations of snow in all northern latitudes, much to the annoyance of the traveler, and an injury to all vegetable matter which it may embed beneath it.

5. Having been in use a few years it becomes dilapidated and is the "sport of the storm."

6. However well and substantial a post and board fence, for farm purposes, may be built, it does not prove to be a barrier to an unruly bullock or a roving horse.

7. It is not fire proof, and is extremely transferable, without negociation, on the lines of highways, railroads, canals, \&c.

\section{MODERN WIRE FENCES.}

This class of fences have been (to some extent) introduced throughout this and adjoining States, and by many was considered a valuable improvement upon other systems heretofore adopted, 
but time, with practicable experience, found many objections, among which the most prominent are the following:

1. The posts used are of wood, set in the ground in the same manner as when used for post and board fences, and in like manner subject to the caprices of the frost and rapid decay.

2. 'The wire is fastened to the posts, and strained to nearly the full power of its tension, (fences are generally made in warm weather) and in extreme cold weather the wires are foumd to part ; the reason of this is olvious: the wire being strained when warm to nearly the full power of its tension, when in a state of expansion, in accordance with the height of temperature, and when the temperature is approxinating zero the wire must contract, and that too when the metal has far less power of tension, and consequently, must sever, and is no longer a fence.

3. In the spring of the year when the ground is soft and limpid, the posts reaclily yield to the inclination of the greatest power of attraction, and thus the whole line of the structure is thrown in a line of disorder.

4. This class of fence is found to be dangerous to animals on account of its "invisibility;" it is well known that at a short distance only, a line of posts are seen, and no visible obstruction between them is discovered. The animals enclosed by a fence of this description, in their playful pranks, or flight occasioned by fright, rush on and only aim to aroid the posts, and seeing no other obstruction, still rush on, and are only impeded in their conrse by the wire, and not unfrequently at the loss of life, or usefulness.

\section{STONE WALL.}

With regard to this class of fence for enclosures, it may be said to have no objections in some localities, yet there are objections even to a beautiful stone wall five feet high ; but in some localities all the objections which can be alleged against them are not equiralent to their utility and usefulness. It cannot be alleged that a stone wall is not visible : but it is however, a fruitful source of snow drifts. It cannot be said that a stone wall will "freeze out," but if the structure is not based upon a permanent foundation on lines rumning east and west, the expansion of the ground by the action of the frost on the north side, will cause the wall to incline to the south during the winter, particularly if snow is deposited on the south side, (which is a common occurrence) and in the spring the frost is removed by the rays of the sun and the attraction of the snow upon the frost; thus, oy the accumulated weight resting upon the south sile, and the soltness of the ground, !he wall is still further inclined, and in the space of a few years the wall tumbles, and must be relaid. Tut as this class of enclosures are indispensable, it may not be considered presumptuous in giving a few hints as to the best mode of erection.

It is a well known fact, that there are many sections of country where the quantity of stone upon the surface are a perfect barrier 
to culture, and the soil is valueless, in that respect, unless remored, and as a natural consequence, the most profitable disposition of them is to convert them into "fencing materials." If the ground is wet, and of that class of soil which is denominated "heavy land," a trench of sufficient depth should be dug and filled with small stone, and should be at least one foot wider than the foundation of the wall intended, and then if the stone are al! carefully and permanently laid, inwardly inclined, neither frost nor wind will effect a wall of that kind, and will remain perm:nent many years, if not ages. But in localities where stone must be "quarried" ostensably for the purpose of making a fence, and those stone to be transported any considerable distance, cannot at the present day be considered profitable, when other materials can be furnished at far less expense and equally permanent, comparatively.

\section{STUMP FENCES.}

A fence made of large white pine stumps is the most durable and permanent of any wood fence, and forms (if well made) a perfect enclosure for all domestic animals; but as it is also the harbinger and protector of noxious plants, which baffles the skill and perseverance of the most careful farmer to exterminate any regetation which may spring up in its midst. No careful farmer will tolerate them as division fences, and are only properly located when made on the bank of a washing stream, or upon the borders of the forest.

\section{ORNAMENTAL FENCE.}

Of this class there is at the present day, snch a large (and might almost say) an endless variety, that it would be a task of too great magnitude to enumerate or analyze their respective merits or demerits.

There are several varieties which have amply tested their melits as to durability, if not in beauty of design, but all belong to one principle of structure, and of material, and that is wrought iron pannels erected on stone, some have wrought iron and others cast iron po:ts, permanently secured in stone, fences or railing, are now standing monuments of their durability, having with-stood 'Time with his destructive elements for nearly a century in this country, and to all present appearances will with-stand his ravages another century.

The introduction of cast :iron fences are of a more recent date particularly in this country; and therefore have not the practical test as to the utility or durability. But it is however evident that a cast iron fence does not possess the same power of tension as that of wrought iron of the same weight of material, but it is also evident that a configurated ormamental fence can be made at less price than wrought iron of equal dimensions.

There are also many designs of wood fence now in use, many of which have been made at an expense equivalent to the expense of 
an iron fence, and as the many difienlties are sn apparent, and have been so thoroughly tested as to durability, that it is deemed unnecessary to go into a detail, suffice it to siay that wood posts even if of red ceder are as subject to the action of the frost, as any other wood post set in the ground and any kind of ornanental fence however configurative, if it be thrown out of line or not plumb, is no longer ornamental.

\section{HEDGES.}

Many efforts have been made to introluce a "living fence," or in other words a "hedge row."

Whatever may be the objections to this class of enclosures or whatever may be said in their favor, experience seems to have tested the practicability as well as their utility. Various classes of the vegetable kinglom has been called into requisition, and notwithstanding the persevering efforts of many of our most enterprising citizens to cultivate the different kinds of hedere fence there are at the present day, comparatively, but extremely few now in existence in the United Stit:s, which can be nroperly termed a fence. The time required and the exprense incured for their culture are alone sufficient reasons for their not being generally adopted. But hedge fences also, have their objections in other respects, one of which is of natural consequence and that is the shading of the adjacent ground, strangulation of domestic animals and the shelter for the obnoxious, but as there are not enough in this country to make it an object of discussion it is deemed unnecessary to say more of them.

In reviewing all the foreroing difficulties and the produring causes, we cane to the conclusion that a different principle should lic adopted which would remedy many of the dilliculties heretofore existing, and that a system might he so armanged that would be equalIy adapted to all classes of soil and all localities. 'To effect this a series of experiments were made upon the power of tension on various forms of cast iron, and finally in 1847, the undersigned obtained letters patent for improvements in iron post hurdle fence. The post patented in connection with this fence was so constructed as to be inserted into stone with a cast iron pin or tenon.

The manufacture of wool pannels of picket fence was then commenced and attached to the cast iron posts secured in stone.

This class of fence was well received and various specimens of designs were exhibited at the annual fair, of the N. Y. State Acricultural Society, and also at the fair of the American Instinte, both of which awarded medals to the exhibitor. Subsequently wrought iron bolts for tenons were introduced insteat of east iron. This class of fence both of wood cast and wrought iron pannels, are now in use in this and other States, and is placed on all classes of soil, from the solidity of rock, to the soft muck or clay, and all erected on the same principal, which is a stome of wutlicient size, wholly immaterial as to its form in which a hole is drilled to recerve the tenon of the post. The stone in all cases is embed- 
ed in the ground even with its surface, the post is then inserted and made plnmb and secured with brimstone. It may here be remarked that a stone or block of wood laid in the ground, and even with its surface cannot be injuriously effected by the action of the frost.

By practical tests as well as by observation it will be discovered that the raising of the ground does not affect the position of a stone or $\log$ of wood when horizontally imbeded in the ground, and the reasons are obvious, at the commencing of the freezing of ground, it expands in the proportion to the depth the frost has penetrated, and if not to the depth of the thickness of the stone or log, the ground expands and raises above the stone, causing a cavity where the stone is embeded, the stone cannot be elevated by the frost, and consequently, still retaining its first position. But when the frost has penetrated to the depth of the thickness of the stone, then the stone is elevated in proportion to the expansion of the ground, and at the same time remaining in its former parallel position.

Thus a fence erected on stone imbeded as described, cannot be in any wise injuriously effected by the frost, as the fence still retains its perpendicular position, and when the frost is wholly removed in the following spring, the fence is still found as when first erected.

It may be asked why then does the frost effect a stone wall, so injuriously,-In reply it is only necessary to state that a stone wall is generally a close structure, and while on the one side the "Northem blasts" have full power to chill and congeal, while on the other side they have no power until they chill the whole atmosphere, and further whatever degree of frost may have penetrated on the one side, the warm rays of the sun is calculated to undo what the frost has done measurable, while on the other his "genial rays" has no influence.

Again-It may be asked what are the practical effects of frost on a post set perpendicular in the ground, in other words why does a post "heave out?

The reply is, a wood post set in the ground, and reaching below the penetration of the frost is operated upon as follows; taking for example a clay soil, (being the most adhesive and the most liable to expand,) a post being placed in the ground below the penetration of the frost, the first operation is the surface of the ground becomes congealed and its encrusted surface becomes firmly attached to the post at its surface-by the gradual penetration of frost the ground expands and consequently elevates the post full equal to the expansion, and when the post is thus elevated a vacuum is made beneath the post and as a natural result is filled $n p$ by the semi-liquidated earth-and on the frozen ground being dissolved from the post, immediately on the return of the first warm rays of the sun, the post is completely liberated and left resting upon the earth, filled in beneath it, and each succeeding winter produces the like results. 
Ilaving thus briefly given the practical results of the action of the frost upon timber placed perpendicularly in the ground, and the effects of frost upon walls on wet soils. It is deemed proper to state that large quantities of woorl pannels, as well as iron prannels of fence have been erecterl and supported by east iron posts which are secured in stone as heretofore stated. The stone used are of almost all varieties which can be drilled and of such form as mature gave them, and the only requisite is, the bulk, weighing from fifty to one hundred or more pounds, according to the weight of the structure they are to support; fence of this description has now been in use since 1847 and is placed on all the various classes of soil, and in the different climates from Maine to Georgia, and up to this date no complaint has been made as to the permanency, as well as stability of this plan of fence on any and all classes of soil on which it is erected.

Experiencing many difficulties in mautucturing an article of fence which could lie adapted to all grades of surtace as well as different courses which was not the case of this invention, an effort was made to obviate this diffeulty and also devise some plan whereby iron could be used instead of wood, not only for ornamental fence but also for Farmers, Railroads, ITighways, Cunals, \&se. It was an important consideration that all classes of these fences should be flexible, that is, a plan of fence should be so constructed that after it was manufictured and prepared for erection, it might be placed on any undulating as well as level surface, and also on any desired course crooked or straight, and also reduce the expense of manufacturing iron fencer, and thus bring it within the means of all classes of our fellow citizens, and also to be the means or introlueing a permanent wrought iron farm fence, which would be a substitute for the present modes now adopted.

And after devoting much mental as well as plysical labor for the past four years and on application, letters Patent were granted to the undersigned for improvements in flexible fence, which is applicable to all classes and grades of fence mate of wood or iron, farm or ornamental fence. The same principal of erecting this fence on iron posts, secured in stone, as heretrfore described is still athered to, or in the mammer hereafter described either or both will remain a permanent principal of its structure.

Iron Farm fence will be first considered; the necessity for a change of ingredients for farm fencing hat heen biefly discussed, and the next thing to be eonsidered is what will be the material? The answer is: Our country abounds with iron ore, and as man extracts the materials of the surfice of the earth, Providence has laid in store the necessury sulstitute under the earth; as the native forests have gralually receled by yielling to man the demands male for supplying his wants as a suhatitute for fucl, he directed man to look under the earth for a supply, and so as to many other of man's wants and particularly so, with regard to materials for enlasing his premises, man has removed the once abundant supply of 
timber suitable for enclosing the soil upon which the forests stood. Ife now instinctively directs him to look beneath it for a substitute and which is far more durable, and in every particular far better. It may be asked can a substantial iron fence be made at a price within the means of a farmer? In answering this question it is proper to state thit many farmers who have heretofore been in the practice of annually resorting to their own "woods" for a supply, and who never have made any account of the ralue of timber, nor the value of the labor bestowed in converting it into fence, may at the first impression say that they can "make fences cheaper," but the results of mature deliberation will unquestionably remove every such theory.

\section{FARM FENCE OF ALL IRON.}

This class of fence is made wholly of iron, the posts are of cast and wrought iron combined and one of a peculiar construction, and are of sufficient strength to resist any ordinary pressure. The bars extending from post to post, are wrought iron rods, of any desired size, from $\frac{1}{4}$ inch to $\frac{1}{2} \mathrm{inch}$, and also any desired number may be used, and may be made sufficiently close, so as to enclose securely the smallest domestic animal, and sufficiently strong to withstand the attacks of the most unruly bullock. These bars or rods are all united to each other by wrought iron stantions and posts, in such a manner that they camnot be forced apart, and thus preventing any animal intended to be guarded from passing between them, in it is also braced in such a manner that whatever may be the length of the stretch between the posts, the rods cannot sag in the middle, this fence is visible.

The posts and stantions, as well as the rods, are all of a sufficient size to be seen at a distance and have a uniform appearance, and the whole structure is rather ornamental, than otherwise different from the ill proportioned and the widely contrasted appearance of the wood post, wire fences of the present day.

This plan cannot be effected by the action of the frost in any manner whatever, neither by the expansion or contraction of the iron rods, nor effect the post on any soil. It is also extremely simple in its construction, any person of common mental capacity (not a mechani.) can erect this fence, and more than he can of the common post and board fence. It is also made of any desired heighth, from three to six feet, this class of fence is furnished from one to three dollars per rod, or it is all fully prepared for erection at $4 \frac{1}{2}$ cents per pound.

\section{IRON PRAIRIE FENCE.}

During the time of the invention of the improvement of fencing, the subject of the most feasible plan of fencing the western Prairies was considered in many instances all suitable materials for enclosing these valuable tracts of land, are many miles distant and if wood fencing materials were furnsished gratis, the costs of transpor- 
tation would preclude the undertaking, and hence many of the most valuable tracts may remain unoccupied for many years. 'That same fence as just described is also intended for prairie fence with but one single exception, and that is the posts of the former are secured to stone set in the ground by wronght iron tenons or bolts, (or as hereafter descrited,) and the posts for prairie fence have attached to them wrought iron bars, either straight or in the form of a fork, and are simply stuck in the ground by thrusts; This fence is easy of transportation as many lenial rods may be conveyed by one team on a common road; it has also one other preference to all other clasees of fence it being fire proof, an "ocean of flame" may sweep over the plains, this fence will withstand the conflagration, and aiter it has swept over it, it will stand unscithed and unharmed. This fence is also atfurded from one to three dollars per rod.

Both the farm and Prairie fence have many preferences over all other classes of fence, and deemed worthy the special attention of all classes of interest concerned.

1st. The durability-It is evident that a fence made upon this plan must be durable and will evidently last fifty years without any repairs whatever.

2nl. It is permanent and cannot be broken or injured by unruly animals, and therefore forms a perfect enclosure for all or any purposes intended as an enclosure.

3rd. It forms no barrier nor obstruction to the blasts of the wind, nor the rays of the sum, and consequently does not create the receptacle of large lodgments of snow, or not sulject to clislodgement or prostrating, and also no shate, to the detriment of regetation, all of which are important alvantages to agriculturists, as well as to Railroad Companys, Canals, Highways, \&c.

$4 \mathrm{th}$. It is convenient of erection and transportation, and may be placeel on all grates, on all eourses, on all soils, in fict it is adapted to all localities in all climates.

5. It is as "cheap" as any other permanent fence, which is not one fourth as durable except a firm stone wall.

\section{IRON POST HURDLE FENCE.}

This class of fence is particularly intenter for all localities requiring to be temporarily enclosed, and for lands sulyject to inundittion, \&e.

In some localities the "sniling" of cattle in plsture lands is alopted; that is, a large lot is intended for pasture, a temporary fence is erected to enclose a small portion of the lot in whith the cattle are permitted to feed, and when "feel off" this fence is remover and erected to enclose another portion, and so on. There are also other localities where larre tracts are sulject to inmmation, all the former systems alopted. the II urdle fence to be used for those purposes have been attended with much loss of time and at great expense. 'To obviate the difficulties of enclosing such lands, a new system has been introduced. 
For that purpose a cast and wrought iron post combined, of a peculiar form and construction, has been inrented, and bars of wood or of iron in connection, may be used. The posts (like the Prairie fence) have wrought iron bars attached in the form of spikes for the purpose of perforating the ground to sustain them permanently. The main body of the post is constructed so as to adinit the ends of the bars in grooves, which secures them firmly. The bars are each united to the other in pannels, whether they consist of two or more (as many may be used as desired,) with wire chain. To erect this fence, the first post is thrust in the ground with as much facility as a straight, sharp bar of iron can be put down; the pannel is then brought up and one end of the upper bar is placed on a wrought iron pin on the top of the post, thus determine the place for the next post, which then thrust in the ground, and the other end of the upper bar is next placed on the iron pin, the bars suspending from-the upper bar find their exact position in the posts, thus finishing one pannel, and so on alternately. It can be safely asserted that two men can erect more of this class of fence per day, than the same men can place the bottom rails and blocks of a common worm rail fence. In case of an unexpected inundation, this fence would not be liable to be swept away, though not a barrier to drift-wood or floating ice, which would naturally disconcert the structure without other injury to the materials. On removing this fence, the cart being in readiness, the first post is drawn and the whole pannel is liberated, and the bars are thrown in the cart.The post may remain on the ground, or also be thrown in the cart. The whole is removed in less time than is required to put it up,the whole occupying an extremely small space, as twenty-five rods may be conveniently placed in one ox-cart. This class of fence is afforded, all in perfect order for erection, for $\$ 1,50$ to $\$ 2,00$ per rod, and is admired by some as a permanent structure, being a firm, durable and neat appearing fence.

\section{WROUGHT IRON FLOOD FENCE.}

During the time engaged in the fence business, many applications have been made for a fence suitable to be placed across a stream or current of water, or in places where inundation by flood or otherwise, was of frequent occurrence, and where it was at the same time indispenzable to retain a fence.

A suitable fence of this description, which would answer the purpose and could be made at a price within the reach of those requiring the article, was heretofore deemed impracticable. But the frequent calls induced the undersigned to give the subject his attention, and is now happy to amnounce that he has succeeded in in. venting a Flood Fence, which is not only a permanent fence when erected, but is self-adjustive to the current.

This fence is made wholly of wrought iron, and is so constructed that it may be permanently placed across any common brook, creek or stream, and the only damage it can receive by the swelling 
of the stream, is the prostration of the fence by sections, and lay prostrate at the bottom or bed of the stream. No damage can result to the fence except by being covered by gravel, \&c. And when the water subsides the fence is only to be raised by sections

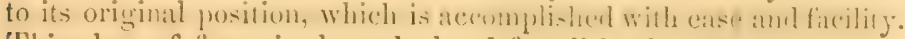
'This class of fence is also calculated for all lands subject to inundation, and need not be remored in any case whatever, and receive no damage unless washed under, or the ground upon which it is aflixed is washed away.

\section{[Description of cut No. 23.]}

Cheap iron door-yard, grave-yard or garden fence, or for enclosing public gromuds, all being constucted on the sume frinciple. For the erection of this class of fence, hollow cast iron pillars are used instead of the common posts ; horizontal rods are then stretched from post to post with intermediate wronght iron stansions, and of any number of bars and heighth. In all other respects it is constructed like the iron farm fence. This fence may be made of any desired size of iron, and can be rendered highly ornamental at a small expense, by the use of a cap picliet bar, as represented by cut No. 23.

\section{IRON PONT (WOOD PANVEL, ORNAMEYTAL PICKET FENCE.}

This alas of fonce (heing the lirst improvement of the Patentee upon any system of fencing, ) has now been in extensive use since 1848 , and thus fur the demand continues to be on the increase. This class consists of a cast iron post secured in stone or a block of

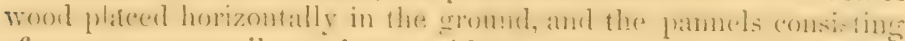
of two or more rails or bars, with or without base, with round pickets or banisters turned in a lathe made for the purnose. This class of fence hns been much improved in its construction, and is now manufactured in accordance with the specifications and claims of the Letters Patent, issued July, 1851, and is perfectly flexible, and adapted to all grades and courses. This fence, when made for ornamental purposes, consists of the first quality of timber in the pannels, - the bars are prorated with conical holes for the insertion of pickets. 'This is done for" a two-fold purpose-one is for the purpose of driving the picksts in the bar sufliciently tight, without splitting, to prevent any water penetrating the bar, and for a free circulation of air on the underside of the bar, to prevent decay around the picket. The other is-to cause the pannel to be flexible; that is, the pannel may be racked sufficiently to ascend or clescend any desired grade, still retaining the perpendicular position of the banisters and posts. The bars are joined to the posts with iron clasps of a convex form, upon which is surmounted an iron ornament of any desired design. A wood pannel thus constructed

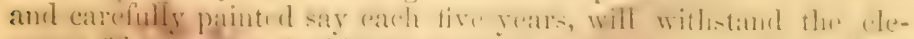
ments fifty years. And if the artist wi-hes to display his slibl at 
deception, will make it appear and resemble a henvy, massire iron fence. This class of fence (or railing) is afforded for 25 to 75 cents per foot. A suitable gate is furnished with each fifty feet at the same price.

\section{IRON FLEXIBLE ORNAMENTAL FENCE,}

snt railing suitable for door-yaris, veraidah , airies, crmetery plots, gardens, balconies, \&c., \&c. Also, ornamental door and window guards, or grated air doors, and window-shutters, \&c., \&c., all of numerous styles and designs of architecture, embracing over one hundred variuties.

The pannels of fence are of wrought iron, made of any desired size of bar, from one quarter of an inch diameter to one inch; and also of every desired form, round, oval, square, or flat-beaded iron. All the designs used in the construction of fence of this class, are also flexible---adapled to all grades, or courses, without any reference being had to the locality. In the invention of this fence particular reference was had to obviate the difficulties in the construction of fence at manufacturing establishments, without accompanying drawings of plan, or diagram of the location.

All the varieties of this plan of fence $m: y$ be manufactured in quintities, and shipped to any place as an article of merchandise; and all that is required of the purchaser is to determine the length of fence required, and the number of gate-ways. He may then select his design or configuration and remove it to any locality and erect it on any desired grade or course. 'I'hat is, if it is' to be placed on a straight line and on level ground, it is ready for erecting. Or, if he wishes to erect the same fence on different courses z gzag or otherwise, the same may be ereeted thus without any alceration whatever. Again-the same may be placed on an undulating surface (up-hill or down-hill, or both,) crooked or straight, without any alteration or extra trouble whatever. In case the pannels should extend beyond the distance required, no other tools are necessury than a cold chissel to cut the hars at any given length, and it is then ready for erection. It is unnecessary to spenk of the slurability and permanency of this plan of fence. It is made whol- of wrought iron attached to cast and wronght iron posts or pillars, which are secured to suitable sised stone with wrought iron bolts, or according to the new improvement as is liereafter described, all of which materials are denominated indestructable. Nuch might be said in favor of this plan of ornamental fence abore all others, and will name only a few.

1st. It is the only principle or plan discovered in this or any. other country which will admit of the same fence being manufact'ured and so constructed that it will achlapt ifsilf' to all localities, all grad s, and all comrses, without any reference being had to profile or dingram; consequently, is an article of common meachandise.

2d. It can be made plain or ornamental, as desired.

8d. It admits of a larger varicty of designs than any other plan cver before introduced. 
4th. It is a more permanent structure according to the weight of materials used, than my other plan now known.

jth. It can be manufactured at at less cost than any other fence equally ormamentat, durable aud permanent.

Gith. It can be more conveniently and casily erected on any locality, at less cost, requiaing no skillful mechanic, or variety of cools and implements.

Tth. And consequently can be afforded at a less price.

All the above varieties and styles of articles here described, are manufactured by mahinery invented and mote expressly, and is matented for that purpose. The whole works are conducted under the immediate stepervision of the Inventor and Patentee, who derotes his whole time and attention to the improvenent of the various plans and styles of fence, and railing. And all articles will be made in a style and manner which will be satisfactory to the public, and afforded on as reasonable terms as any other estabtishment in the United States. Each of all the designs of fence or railing, has a suitable design of gate-way, with heary iron pillurs or posts if desired. And one gate-waly with suitable poots is furmisher with each class of fence, one to each fifty feet of fence, without extra expense per foot. This class of fence is delivered to older rarying from 10 cents to $\$ 3$ prer lineal fuot, according to the weight of iron used in the construction.

\section{CAST IRON FLEXIBLE FENCE.}

This class of fence is constructed upon the same principle as all the other classes, alapted to all grades and comres, and is furnish"ul of any desired weight of metal, and of varjous designs, and is afvorded from $S 1$ to $\$ 5$ per lineal foot. $A l l$ and singular of the "nove styles and varieties of fence miling ce., is made of any desired lecighth from two feet, to six feet, inclusive:

\section{IRON FARM GATES, AND GATE POSTS.}

This invention consists in the improvement of farm grate ways. The gates are made wholly of wronglit iron, and are so constructed that they cannot sig or droop, and made sufficiently strong, to resist eny ordinary pressure more than any common farm wood gate. 'The sate posts are of wrought and cast iron combined, and inate firm and substantial and convenient to open and close. These gates are also intended to be placed on any locality, whether in cumection with wrond fence, stone wall, or any other structure. 'They are furnished for 85 to 515 , per piece.

As almost all the within described fence is calculated to be erect7. by being secured in stone, or the palent base, it became neeces"n to have a proper machine for the purpose of drilling suitible

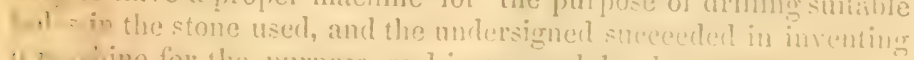
Y. a vine for the purpose, and is soctured hy letters palceiti, ant a na.m ir all localities where contracts are of sulleient magniturle 4) whrant the jimoral. And stone alren ?y drilled are furnished at thr: works to those who desire them. 
As before stated the undersigned has been engaged in the manufacture of fence for the past six years, and during that time had not only opportunities of discovering the defects and difficulties attending the old plans of fencing, but also discovered many defects and difficulties attending his alledged improved system, in arlapting it to all the various soils, surfices and locations in different parts of our country. The first principle adopted was a firm and unflexible structure, and orders were frequently received accompanied with diagrams, representing rarious conrses, circles, angles, \&c. \&c. Also to be placed on undulating surfaces, and not unfrequently the same diagram representing sereral grades, and also several courses.

It was found to be extremely difficult, as well as expensive to manufacture fence in compliance with that class of diagrams, and consequently a remedy was sought, and after much difficulty it was found simply in the present coupling clasps, and conical holes in the bars, which has been more fully explained heretofere, which improvement letters patent were issued July, 29th. 1851. And which proves amply sufficient to overcome all that class of difficulties.

But there existed another important objection for the general adoption of this principle of fencing, it has been heretofore stated that permanency and durability, were the main objects desired to be attained, and consequently iron posts to be secured in stone, next, to so construct a fence as not to be injured by frost, \&e.

In many places it was found that suitable stones were difficult to be obtained and in some localities almost impracticable on accomnt of the expense, and for a substitute, wood blocks were frequently used which were cut to a proper length and placed horizontally in the ground, and the posts secured into them. It is true that this plan was resorted to, only in cases of emergency, but was notwithstanding, contrary to the main principles adopted.

Various experixents were tried with the view of remedying this difficulty ; to form a base of cast iron for the post to rest in was found too expensive.

To extend any form of cast iron post into the ground of sufficient depth, if of proper strength was also found impracticable. Straight bar's of wronght ir. nu wats also found not to answer in many platees, as it admitted toomuch of a lateral motion to the fence, and not of sufficient superficial surface to sustain permanency in the ground, and these difficulties were found to apply to all grades of banister fences in most all grades of soil. And here it may be proper to remark that it is not contended that a straight pointed iron, perforating the ground will raise up by frost, and if so, it will again sink to its original depth when relievertirm the frost, but the greatest difficulty existing in this is as follows :

1st. 'To ereet a banister fence of wood or iron bars, some weight as well as a superficial surface suflicient to be effected by wind, is necessary. A fence of this description, supported by posts made 
of strigryt or forlicd bars of iron, is not liablo to freeze nut on any dry soil if placed in the ground one and a half or two feet, and on such soil may be kept erect at light expense. But if wrought or cast iron posts of sufficient power of tension, either straight bars or in a forked form, should be put in the ground unsupportend hy any other fixture, in soft and wet soils it would be liable to as many objections as the wood post. For example: one class of posts with fork bars 20 inches or more in length, was set in the ground subject to the action of the frost, being in a heavy clay loam and extremely soft and mirery in the spring. This fence was made in July, and stood firm until the following spring. But on the frost leaving the ground, the whole line of fence als:umed every conceivahle pesition-fiom 4.5 degrees to perpendicular, and these positions visa-versa. A line of straight bars of wrought iron posts was alsi) tried. This fence was made an samly loame considered a dry soil. 'The pins of wrought iron penetrated the ground two feet and were a half inch thick and one and a quarter inch wide. The posts at the surface were supported by having small stones placed and

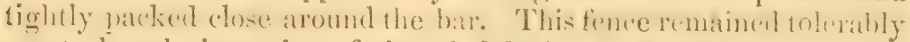
erect, though the action of the wind during the first summer cansed the small stone to yield to the pressure of the wind, and consequently did not retain its original perpendicular position. But the next spring, when the ground was soft, the ferce yielded to every breeze of wind, the stone not sustaining the post. Stone of large dimensions were then furoperly and arefully imberdent around the post, and which now supports it permanently. Both of these fences did, as a natural consequence, raise up by the action of the post in proportion to its expansion, but not materially to its injury. But on the following spring both settled down into the gromol dereper than they were originally placed, and means had to be resorted to to prevent the fence from settling down to its base. These and other experiments were satisfactory evidence that a straight or forked bar of iron of such a size as could be afforded for these purposes, unaided by other fixtures, could not be adopted, and generally used on all soils. It is not contended that there are not soils on which a permanent fence can be erected with posts of wrought iron no larger than before named. But, on the contrary, there are soils upon which a banister fence may be supported permanently upon this plan, but the cases are few.

The principal object of all these experiments was to ascertain the true causes, and devise some plan or principle of erecting all classes of fence which would be adapted to all classes of soil as well as all localities; and so construet a fence that it wonld be permanent and durable, as well as cheap, either with or without stones, and have finally adopted the following plan or devise :-

'The first that will be considered, is all classes of Iron, Fremo Or FARIr FENCE. It has been before stated that many sections of country are totally destitute of stone or timber. For instance: the Westem Praties, for which the forlsed posts have been recoun- 
mended, \&c., and hence the improvement which was secured by Letters Patent in $185 \%$, which consists of the following devise, which was expressly invented to mitigate if not remove the dificulties thus experienced.

The first object was to create a superficial surface of some substance which should surround the small iron bar in the post, and of sulficient dimensions to sustain the post at the surface of the ground. Cast iron was considered the most suitable. For this purpose a square box of cat iron is used from six to twelve cubic inches in size, with a cover having a flange one to two inches wide. This cover is male sufficiently large to admit of strips of lead being inserted between the cover and box. The cover and box each hare an aperture in their centres of the exact size and form of the bar in the post.

To erect a farm or field fence of iron upon this principle, is as follows:-

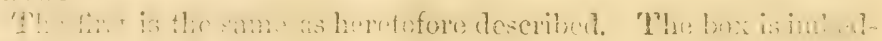
thel in the ground, the cover ouly projecting above; after the box, or

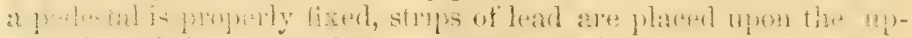
per elge of the box, and the cover is then forced on with a mallet; the post is then inserted into and through holes in the box, and the post is forced into the ground by a sledge-hummer or other derise, until the base of the posts rests upon the corer of the box; the ground is then thoronghly stamped around the box. This system. is followed in all cases where the boxes or Patent Pedestals are used. But, in securing gate-posts or straining pillars for iron furm fence, braces are attached and secured in the same manner as the post.

After the straining pillars are thus firmly secured, other intermeliate wought irin posts are then plined and secured in the stunc manner as the first post, except the brace. 'The intermediate posts are placed the distance apart equal to the length or stretch of the iron bars. All the posts are perforated with double the number of holes required for the number of bars. 'The bars are then run through the proper holes in the straining pillar and irserted into the holes in the wronght iron post and lightly drawn by the serews on the bars. The next stretch is then drawn through the remaining holes in the wrought iron post. This process is continued until the line is complete, or where an angle occurs, at which place another straining pillar is secured in the same manner as the first.--A wrench is then used and the screws are then turned until sufficiently strained, which is known by the intermediate parts being bent in a slight degree in a zig-zag form, which is proluced by the bars being strained almost transversely, thus creating by the intermediate posts, an ample compensation for the expansion and contraction of the bars by the temperature.

This same principle is now used in the construction of all classes of the different kinds of patent fence described in this treatise, except in some localities and the Hurdle and Flood fences. 
After many years of self-denial and devotion to improvements here described, at a great peeuniary loss and eonsequent cmburritsment, the undersigned now most sanguinely belieres that he has suceeeded in so devising the several plans, as here described, in such a manner as to remove many if not all the objections to his plan of metal posts and metal tences, and with the addition of the last improvement here noted, so that in every locality in every part of our widely extended country, his plan of fencing, both farm and ornamental, may be adopteds . The, last invention does not aug-

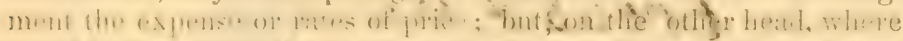

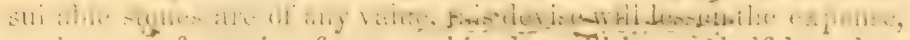
as the cost of erecting fence on this plan will be one-half less than to erect the same on stone.

Iraving thus, in as clear and plain a manner as he was capable, cxplained all the various topies here discussed, he now most humbly and respectfully refer's the whole matter to the l'resident and Secretary of the rew-Iurk State $A$ rricultural Society. MATTHIAS P. COONS. 


\section{UNITED STATES PATENT FENCE WORKS,

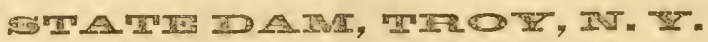

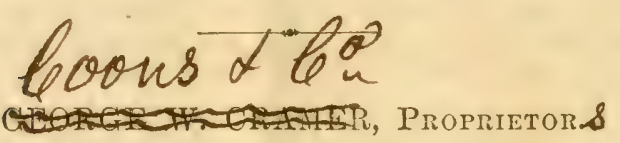

mattilas P. CoONS, Patentee, Manufacturer and Agent of the Works, Troy, N. $\boldsymbol{Y}$.

JOSEPIt WOODRUfF, General Agent for the sale of Manufactured Articles, - Office and Repository at the Ware-house of Messrs. Jalles Beebe \& Co., 314 Broadway, New-York.

AUSTIN S. WELLS, AgEnT,-Office and Repository, HydePark, New-York.

JASON SMITH, ONLY AUTHORIZED AGENT FOR TIE SALE OF Territorial Rigits, Troy, $\boldsymbol{N} . \boldsymbol{Y}$.

\section{A FULL DESCRIPTION OF}

\section{COONS' PATENT FLEXIBLE FENCE AND RAILING,}

Illustrated with woor cuts representing a few of the many designs embraced,-with a scale of retail cash prices at the Works and at the Repositories. All articles ordered will be delivered at 'I'roy or New-York, at the prices fixed by the scale.

Any person wishing other designs than those represented, will please send a drawing, and, if possible, it shall be fully represented. 
25

A SCALE OF PRICES

attached for all the different styles and emetics of COONS' Patent Fence, Manufactured at the United States' Patent

Fence Works, Troy, N. Y.

Sulf-compensating Ir un from Fine for ene losing Fields, Railroads, Highways, Canals, \&c. [For description see page 14.]

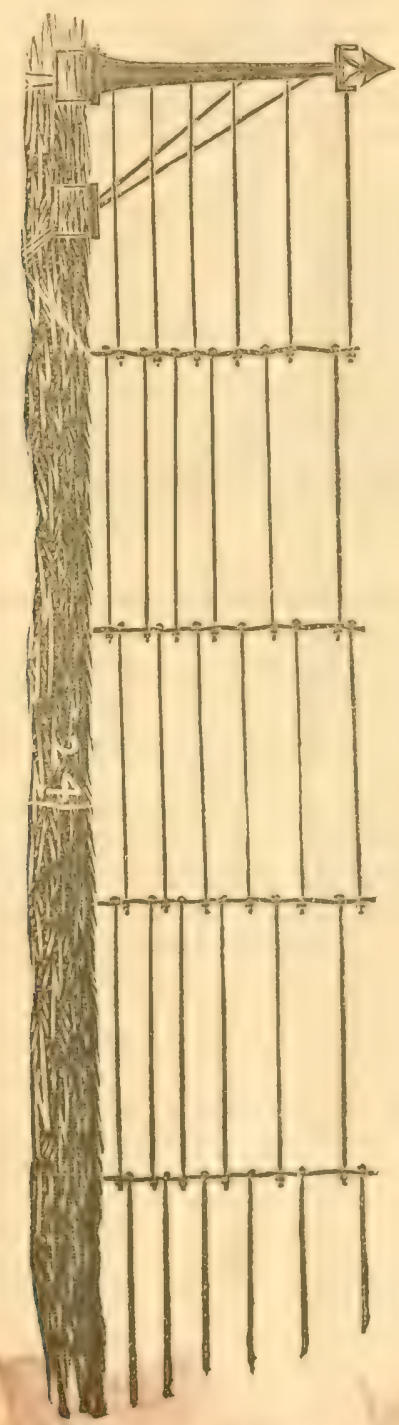


This tariff of prices inclutes two straining pillars and all the intermedinte compensating parts, and all fixtures for tifty lineal rods if required. Fence four feet high with six horizontal bars or wires. Size of round iron. [No's 15 and 24.] Price per lineal rod.

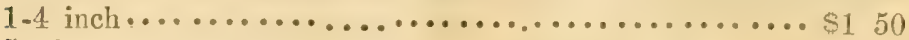

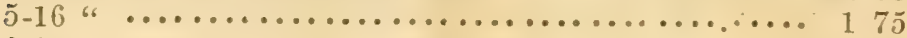

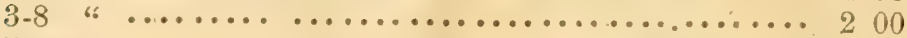
$7-16$ "

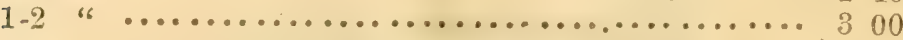

For all larger iron the proportional value of the iron by weight $t$ is only added. All additional bars of $1-4$ inch, $12 \frac{1}{2}$ cents per rod is added for each extra bar, and larger iron in proportion. Flat, quare or oval iron may be used if required.

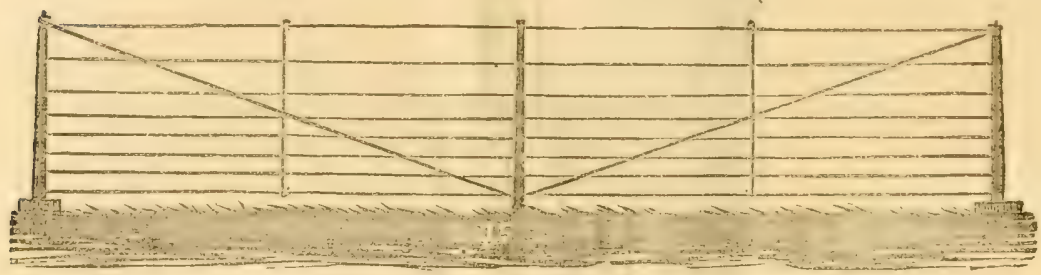

[No. 15.]

Wire bars with two straining pillars and intermediate posts to each 100 lineal rods, is furnished as follows:

No. 6. Wire, 4 bars 4 feet high $\ldots \ldots \ldots \ldots \ldots \ldots \ldots \$ \ldots$

6. " 5 bars 4 " " $\ldots \ldots \ldots \ldots \ldots \ldots \ldots 100$

6 . " 8 cents for every additional bar.

No. 7. Wire, 4 bars $\cdots \ldots \ldots \ldots \ldots \ldots \ldots \ldots \ldots$.............. so

No. 8. Wire, 4 bars.................... 70

6 cents for each additional bar.

No. 9. Wire, 4 bars (5 cents for each bar) $\ldots \ldots \ldots \ldots .65$

No. 10. Wire, 4 bars ( 6 cents for each bar) ......... 60 


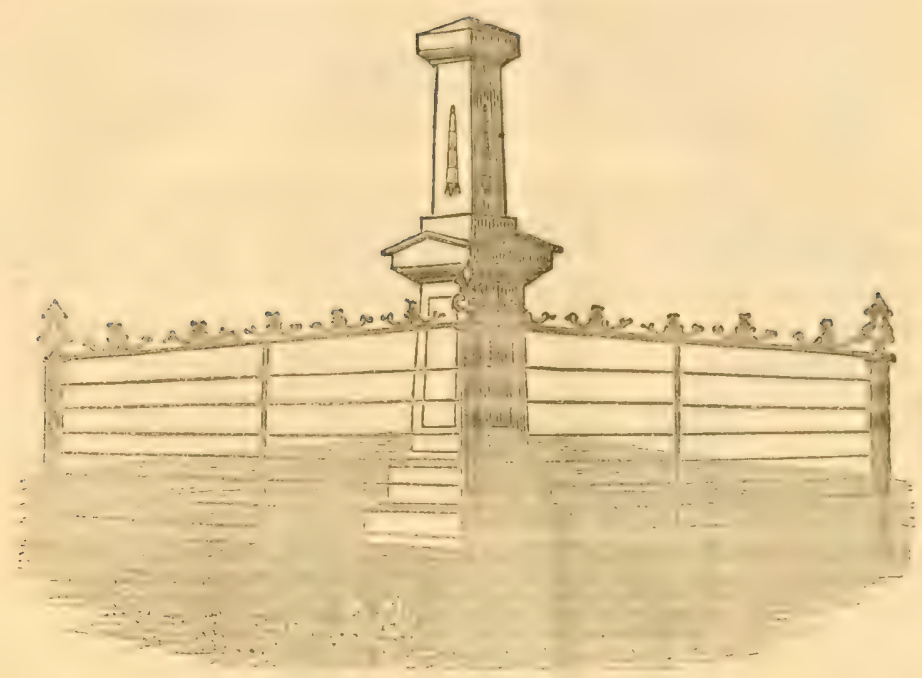

[No. 23.]

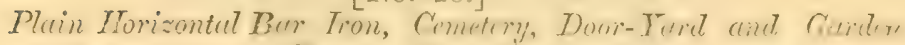
- Fence. [See page 16.]

Size of iron (per foot.) Height of fence 12 feet pannels and $S$ bars

\begin{tabular}{|c|c|c|c|c|c|c|c|}
\hline & 3 fiet & fieet 6 in & $4 \mathrm{fi}$ & fie & i & 5) feet| & feret 6 \\
\hline & $\$ 050$ & 5056 & $\$ 068$ & so & 69 & 5072 & $\$ 0 \quad 81$ \\
\hline & $0 \leqslant 6$ & () 63 & o $10 ; 9$ & 0 & $7 j$ & 0.81 & (1) $\div ?$ \\
\hline & $063 !$ & $\begin{array}{ll}0 & 69\end{array}$ & 075 & 0 & 81 & $87 \frac{1}{3}$ & $094^{2}$ \\
\hline & () 69 & 07.5 & 0 si & 0 & $8: 1$ & () $: 4$ & $\begin{array}{lll}1 & 110\end{array}$ \\
\hline & $\begin{array}{ll}0 & 75\end{array}$ & 081 & $87 \frac{1}{3}$ & 0 & $9+$ & 100 & 110 \\
\hline
\end{tabular}

This elass of fence (rombl irom) is also mate with a top rating, as represented by the cut, and is ornamented with varions designs and is furnished with an additional cost of 10 cents per foot. A, liberal deduction s made when a large quantity is ordererl.

All the foregoing horizontal bar linete is flexible and plater on any desired grade. It is warranted to be self-compensating in all degrees of temperature, without the aid of levers, right and left screws, or other comples fixtures, and is sce?-atlyorting wiohout the aid of "trees, stumps, or buildings." 


\section{SELF-ADJUSTING IRON FLOOD FENCE.}

[For description see page 16.]

The only one of the kind ever invented which cannot be removed or injured by flood and not obstruct the current or rafts of wood, ice, sc.

This is made in pannels of 12 feet or le s, 4 feet high, wholly of wrought iron, and can be permanently secured on any soil or location, without any danger of its being swept away unless the earth is removed on which it is placed.

Size of iron.

1-4 inch iron,
Height of fence.

3 feet 6 inches,
Price per pannel.

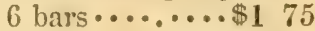

7 bars....... 190

" " "Sufficiently close to enclose ducks, geese, \&c., and 4 feet high................... \$2 50 All larger sizes of iron in proportion.

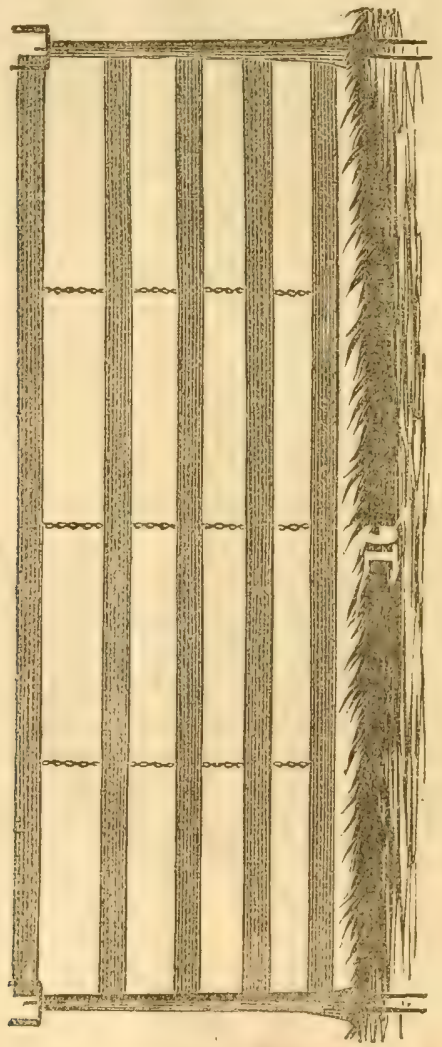

[No. 16.]

CAST IRON POST HURDLE FEITCE.--[See page 15.] 
This class of fence, with wood bars, is sold from $\$ 1$ to $\$ 2$ per pannel, and is male of any desired leight ol elasses, and according to order; it is also made wholly of wrought iron bars and cast iron posts, and is put down with the aid of stone blocks, wood, or other fixtures.

\section{WVROUGHT IRON IIURDLT FENCE.}

This is wholly of wrouglbt iron, the bars of any desired size, and is sold a trifle in advance of the iron firm fence.

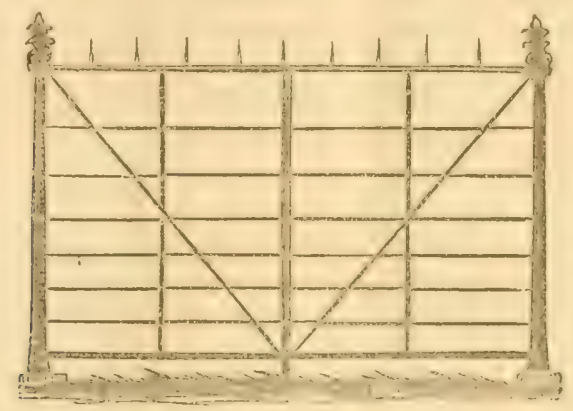

No. 22.

WROUGHT IRON FENCE

for enelosing Cemetery Cimumls, or any similat purpose, wih the top picket; hat the salmg price as that of $N(1.2)$, without the picket; bar the same in proportion as the farm fence, with the top bar without the pickets. 'The bar is charged in addition., 


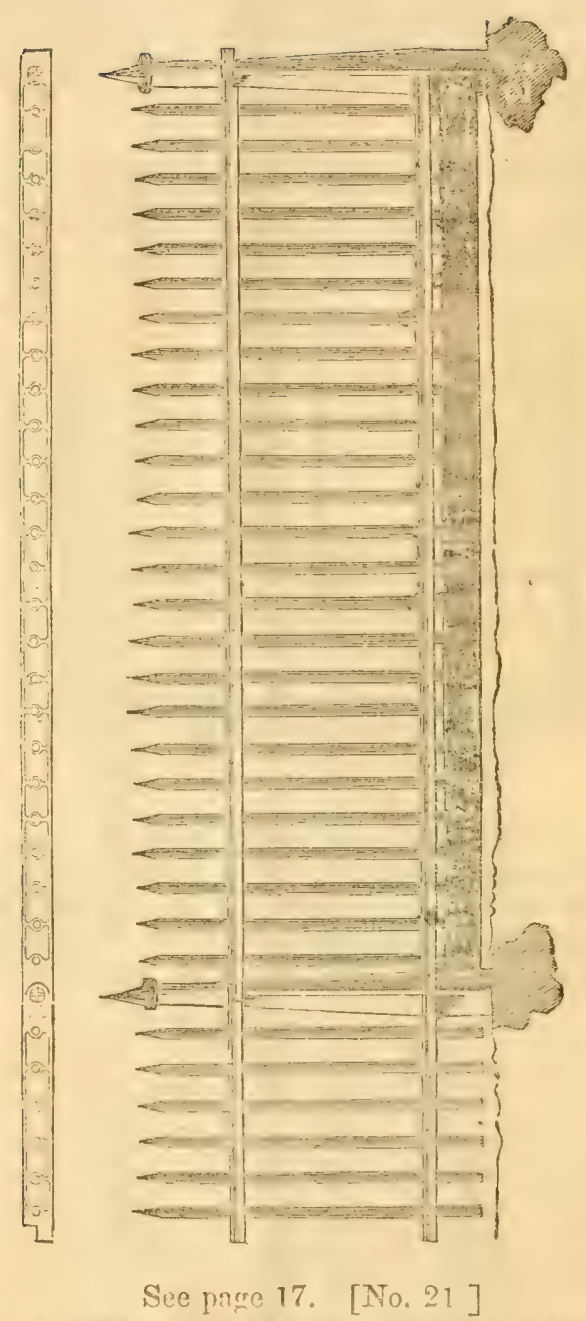

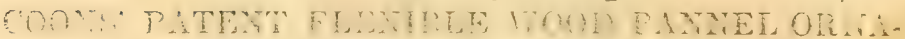
MLNTAL FENCE, with cast iron posts and clasps, in pannels of 12 feet in length.- [Two bar and banister fence.]

This class of fence admits of a rariety of styles, both in cyulity and design; the price rangiug from 20 cents to 75 cents per thut, but the tariff of prices alfixed are for fence of the best of materials, 12 feet pannels, including iron posts, patent clasps, oruments, \&c., and gate to cach dify feet im huled, if recpuired, extra posts, clitsps, ornaments and gates, at cost. 
Fence 3 feet high..................... s0 38

" 3 " 6 inches high............... 87

" 4 " high................... 4.

" 4 " 6 inches high................. 50

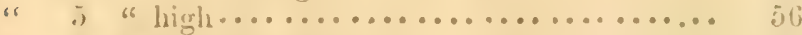

" is " 6 inches high $\ldots \ldots \ldots \ldots \ldots \ldots \ldots \ldots$. 63

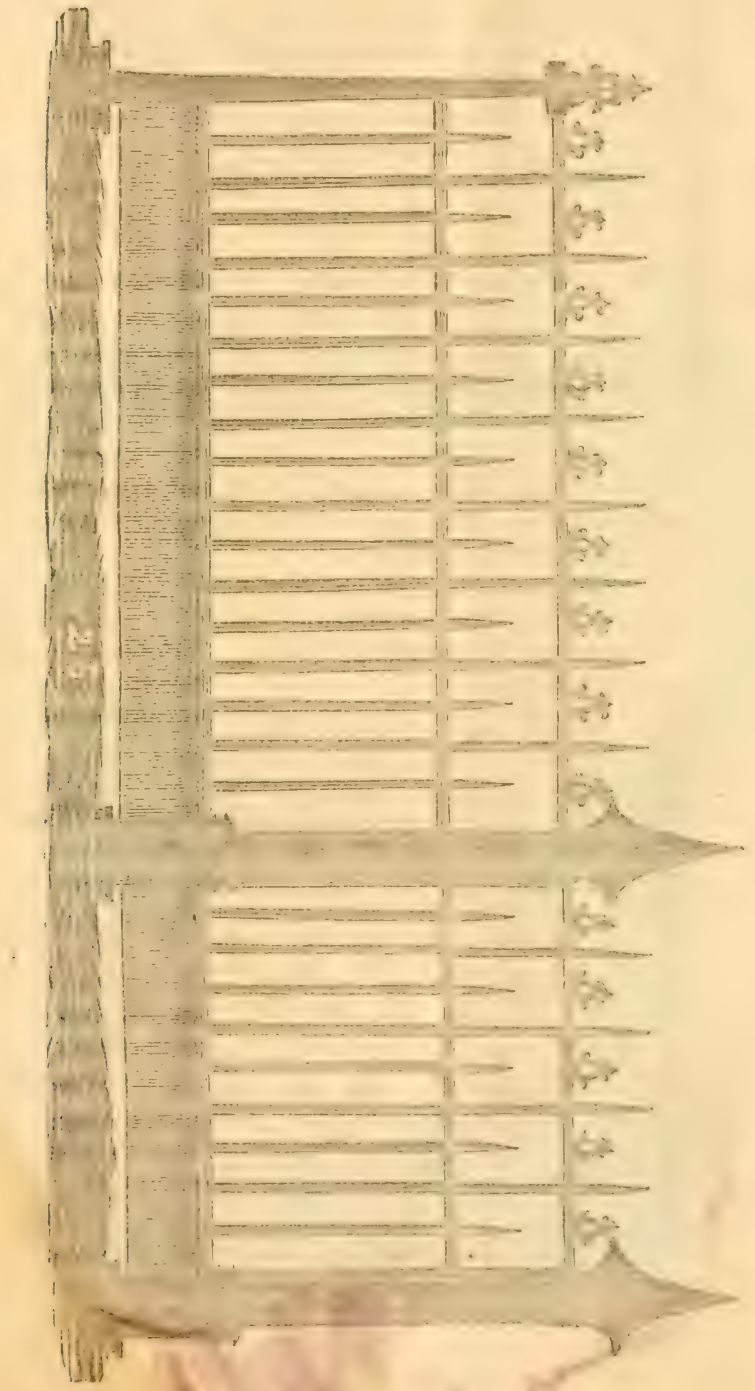


[No. 25.]

Represents the same class of fence with three bars extra ornamented, but in all other conditions the same as No.21. This tariff does not include the top liar, ormanents placed between the pickets. Those ornaments and all extra posts, clasps and gates, at cost. Pannels 12 feet; one gate to each fifty feet, with posts, \&c.

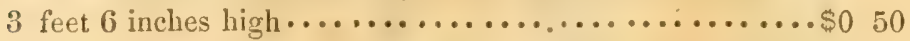

4 " 4 "......................... 56

4 " 6 " 6 " 6 " $4 \ldots \ldots \ldots \ldots \ldots \ldots \ldots \ldots \ldots \ldots \ldots \ldots$

5 " 6 " $6 \ldots \ldots \ldots \ldots \ldots \ldots \ldots \ldots \ldots \ldots \ldots, 69$

5 " 6 " 6 " 6 " $6 \ldots \ldots \ldots \ldots \ldots \ldots \ldots \ldots \ldots \ldots ., 80$

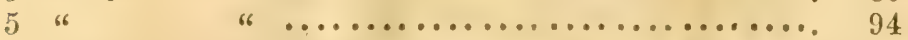

Cast iron pillars and extra ornaments for $\$ 1$ to $\$ 4$, according to weight.

\section{ORNAIIENTAL WROUGHT IRON FENCE AND RAIL- I.NG - [See page 17.]}

This clàss of fence embraces almost an endless variety of styles and designs. The annexed cuts represent but a small proportion of the designs and configuration manufactured at these works, and all represent close meshes; and the tariff of prices affixed, refer only to that class of close and compact fence. Fence with more exterded ineshes and smaller iron, is made from 10 to 20 per cent. less̃ price than those quoted.

All the following quotations include the posts, post ornaments. rosettes, and also one gate to each fifty feet of fence, is included. If cast iron ornamental pillars are preferred, the extra weight of iron is only charged in addition.

Nos. 1, 4, 5, 6, 7, 10, (without borders) are sold as follows:

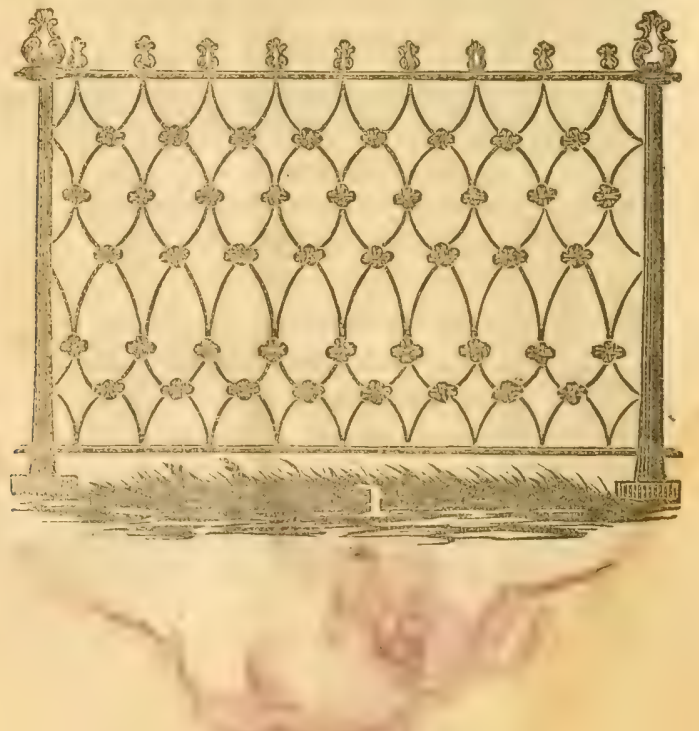



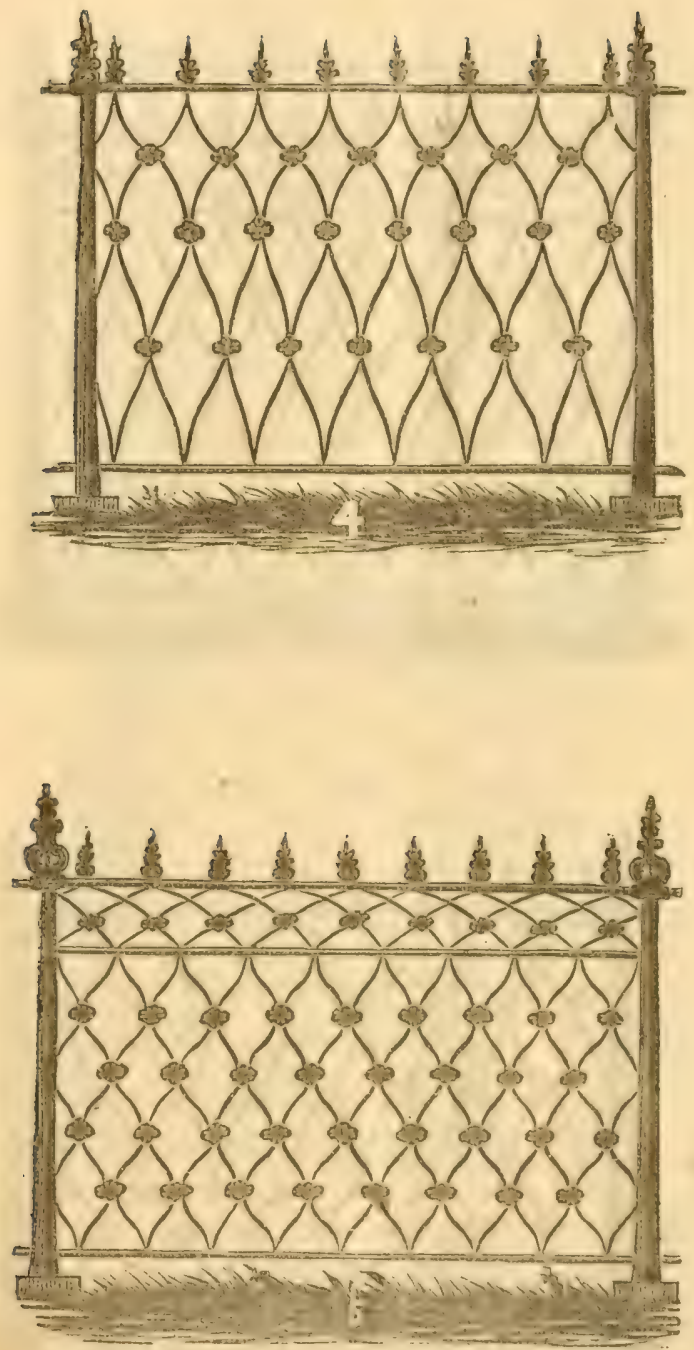

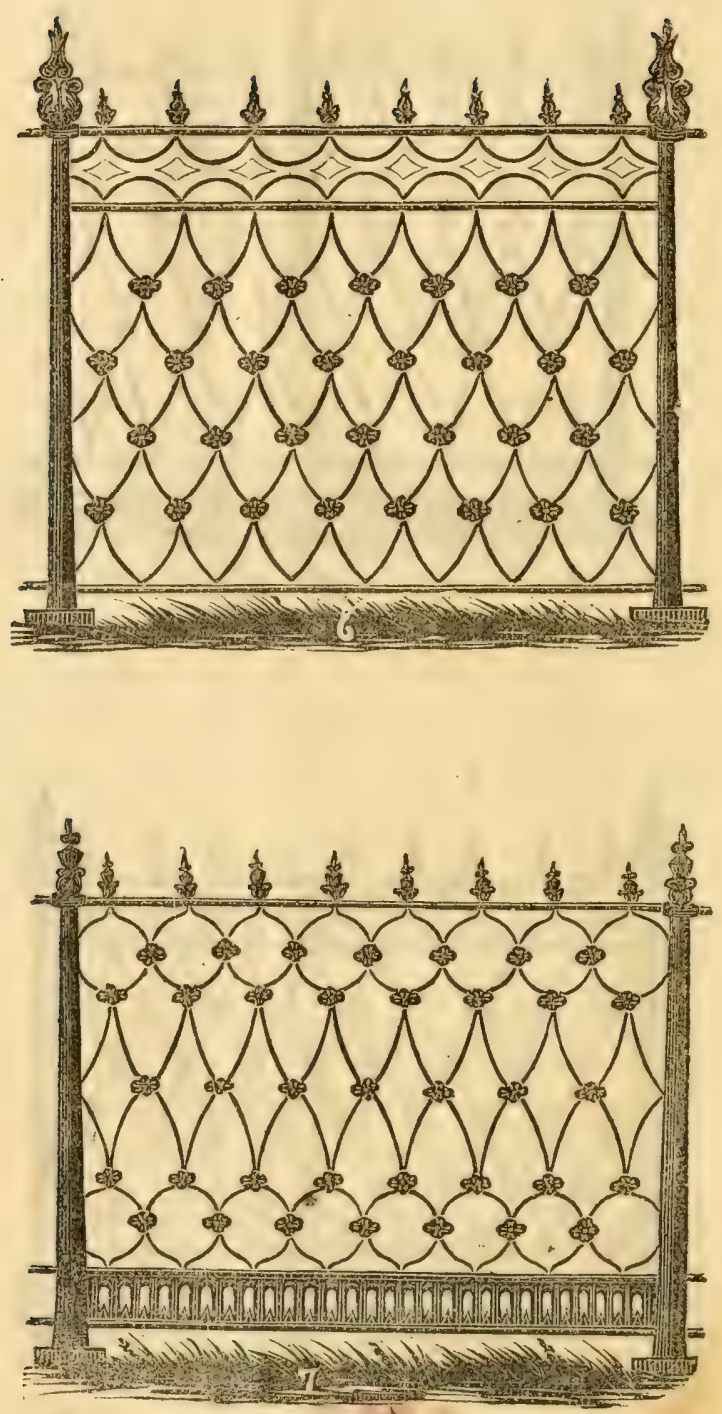


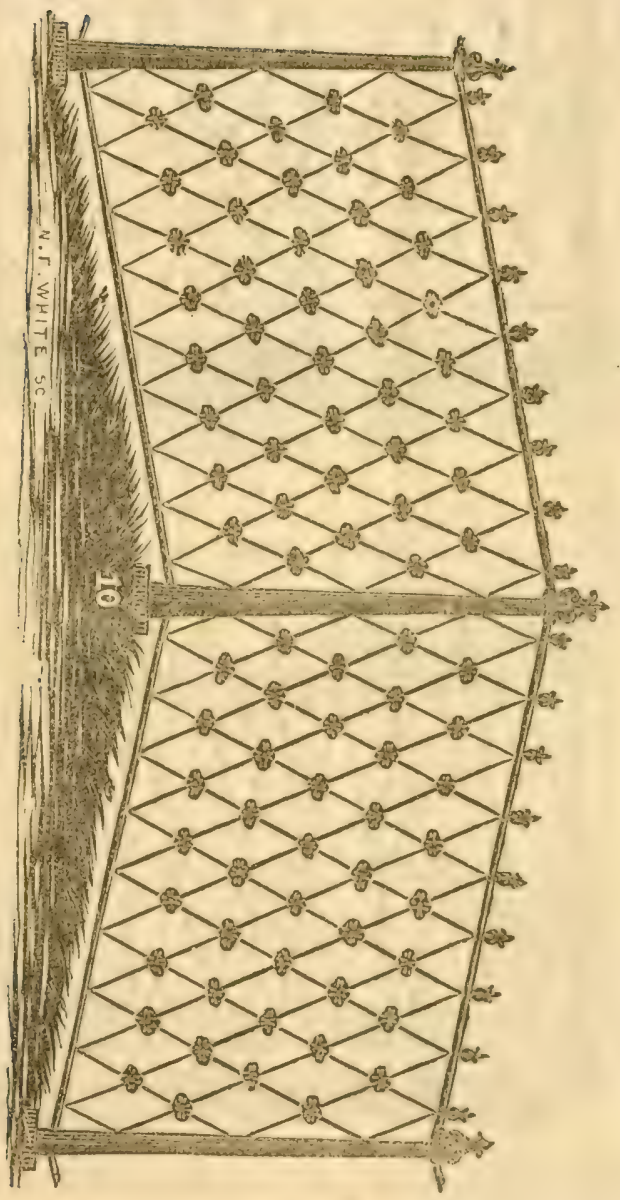

Size of iron. Height of fence.

Round 3 feet $3 \mathrm{ft} 6$ in' 4 i. $\mathrm{t}$ it 6 in 5 feet $5 \mathrm{ft} 6 \mathrm{in}$ (i) feet

\begin{tabular}{l|rr|rrrr|rr|rr|rr|rr}
$1-4$ & $\$ 1$ & 00 & $\$ 1$ & 10 & $\$ 1$ & 20 & $\$ 1$ & 30 & 5 & 40 & $\$ 1$ & 50 & $\$ 1$ & 60 \\
$5-16$ & 1 & 00 & 1 & 20 & 1 & 30 & 1 & 40 & 1 & 50 & 1 & 10 & 1 & 70 \\
$3-8$ & 1 & 20 & 1 & 30 & 1 & 40 & 1 & 50 & 1 & 60 & 1 & 70 & 1 & 80 \\
$7-16$ & 1 & 30 & 1 & 40 & 1 & 50 & 1 & 60 & 1 & 70 & 1 & 80 & 1 & 90
\end{tabular}




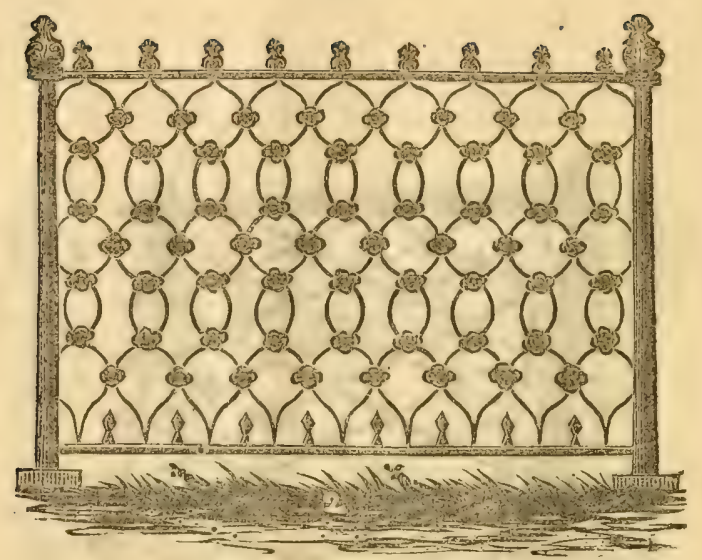

No. 2. Round Iron.

\begin{tabular}{l|llll|ll|ll|ll|ll|ll}
$1-4$ & 1 & 30 & 1 & 40 & 1 & 50 & 1 & 60 & 1 & 70 & 1 & 80 & 1 & 90 \\
$5-16$ & 1 & 40 & 1 & 50 & 1 & 60 & 1 & 70 & 1 & 80 & 1 & 90 & 2 & 00 \\
$3-8$ & 1 & 50 & 1 & 60 & 1 & 70 & 1 & 80 & 1 & 90 & 2 & 00 & 2 & 10
\end{tabular}

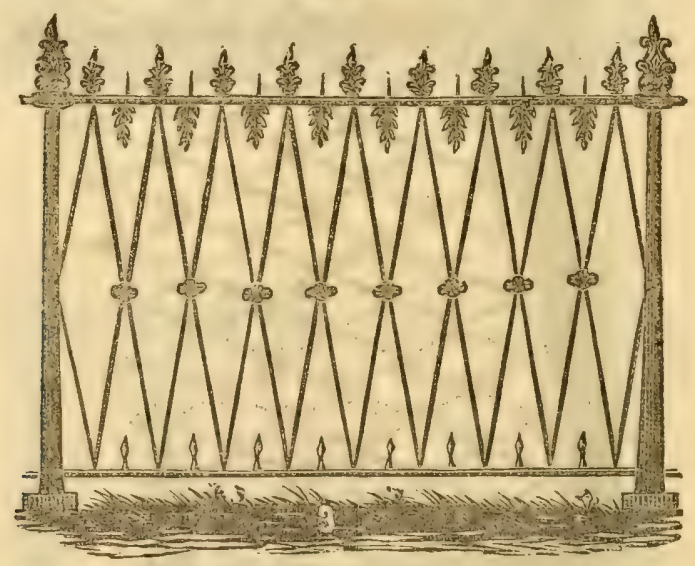

No. 3 and right-half of No.9, (without borders.)

Round 3 feet $3 \mathrm{ft} 6$ in 4 fiet $4 \mathrm{ft} 6 \mathrm{inl} 5$ feet $5 \mathrm{ft} 6 \mathrm{in} 6$ feet

\begin{tabular}{l|rr|rr|rr|rr|rrr|rrr|rrr}
$1-4$ & 40 & 70 & $\$ 0$ & 75 & $\$ 0$ & 81 & 50 & 88 & $\$ 0$ & 94 & $\$ 1$ & 00 & $\$ 1$ & 10 \\
$5-16$ & & 75 & & 81 & & 88 & & 94 & 1 & 00 & 1 & 10 & 1 & 20 \\
$3-8$ & & 81 & & 88 & & 94 & 1 & 00 & 6 & 10 & 1 & 20 & 1 & 25 \\
$7-16$ & 90 & 1 & 00 & 1 & 10 & 1 & 20 & 1 & 30 & 1 & 49 & 1 & 50 \\
$1-2$ & 1 & $12 \frac{1}{2}$ & 1 & 25 & 1 & 32 & 1 & 40 & 1 & 50 & 1 & 63 & 1 & 75 \\
$5-8$ & 1 & 25 & 1 & 38 & 1 & 50 & 1 & 63 & 1 & 75 & 1 & 88 & 2 & 00 \\
$3-4$ & 1 & 60 & 1 & 75 & 1 & 88 & 2 & 00 & 2 & 25 & 2 & 50 & 2 & 76
\end{tabular}

[This class of fence may be made of round, square, oval or flat iron.] 

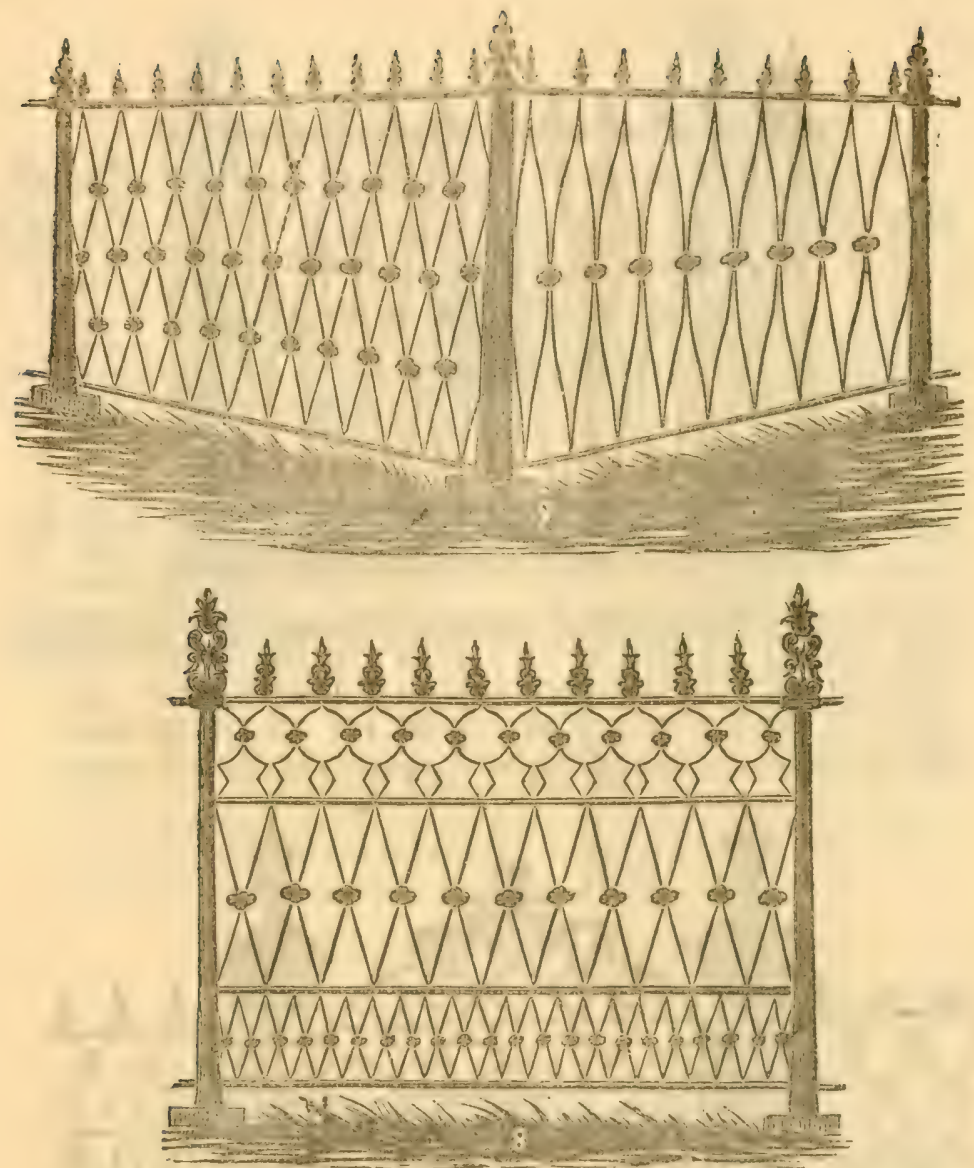

No. 8, with two borders.

Round 3 feet ? $\mathrm{ft} f \mathrm{in}$ in 4 feet 4 ft 6 in 5 feet $5 \mathrm{ft} 6$ in 6 feet

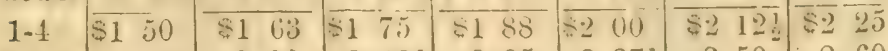

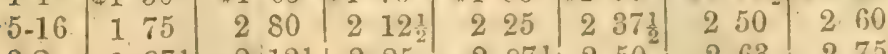

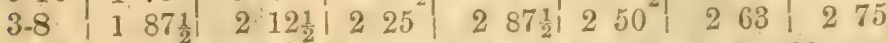
The centre or principal and lower border may be made of larger iron. Thus :

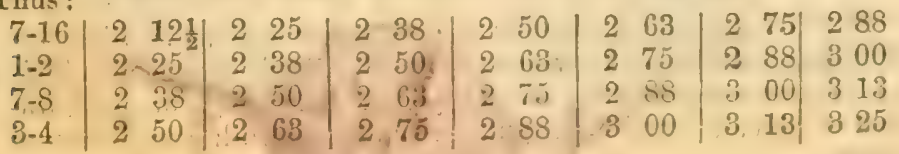




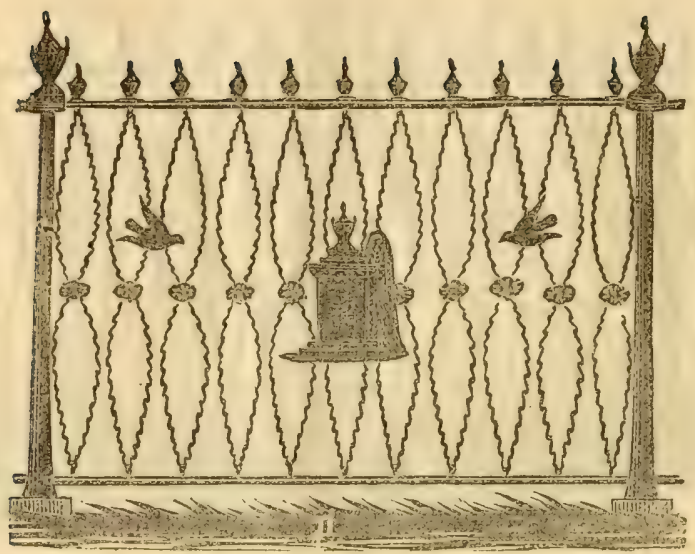

No. 11, with Monumental Rosettes.

\begin{tabular}{l|lll|ll|ll|ll|ll|ll|l}
$-1-4$ & 1 & 00 & 1 & $12 \frac{1}{2}$ & 1 & 25 & 1 & 38 & 1 & 50 & 1 & 63 & 1 & 75 \\
$5-16$ & 1 & 12 & 1 & 25 & 1 & 38 & 1 & 50 & 1 & 63 & 1 & 75 & 1 & 88 \\
$3-8$ & 1 & 25 & 1 & 38 & 1 & 50 & 1 & 63 & 1 & 75 & 1 & 88 & 2 & 00
\end{tabular}

[All the above may be made of round, square, oral, or flat iron.]

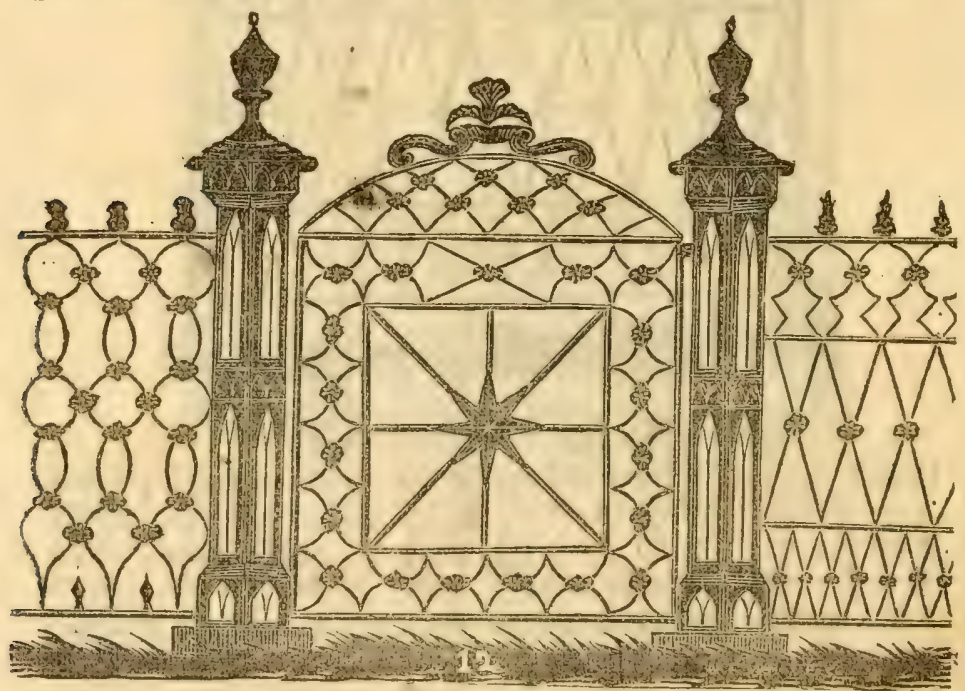

No. 12 represents a wrought iron entrance gate-way, with cast iron ornamental pillars, with sections of pannels attached. This cut is not intended to represent any particular design or configuration of gate, as suitable designs are furnished with each class of fence. 


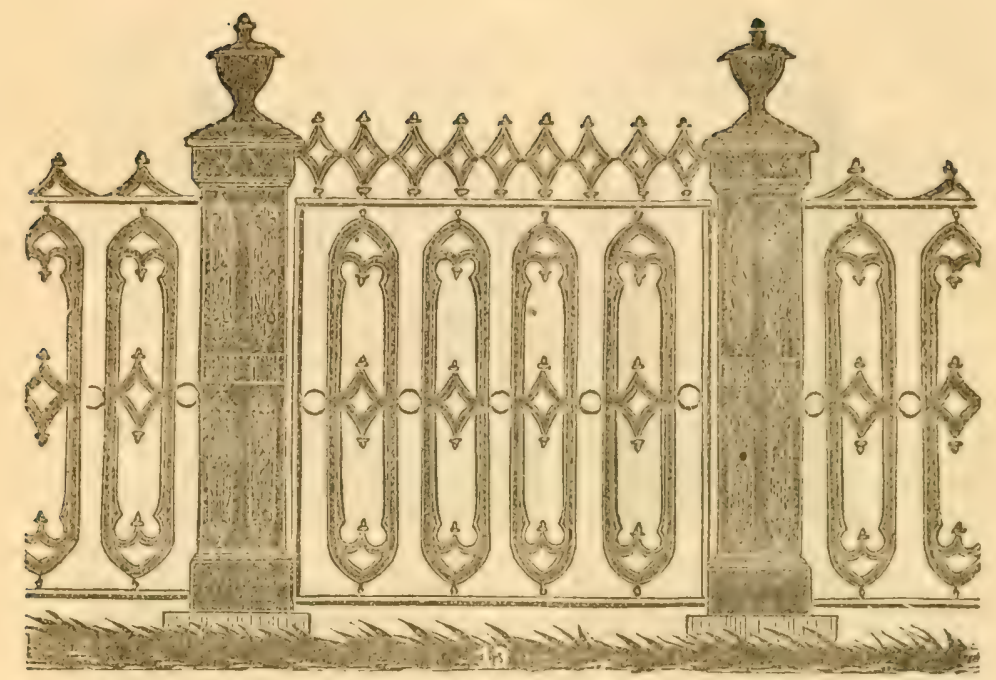

No. 12 represents a gate-way and sections of pannels of flexible ornamental cast iron fence and gate pillars. This class of fence and also No. 1.1, admits of any desired style of arclitecture which fancy or taste may dictate, and also be made light and large, or extremely massive. Any style of architecture which may be ordered, of cast iron fence or railing, will be furnished from two to five feet high from 75 cents to $\$ 5$ per lineal foot.:

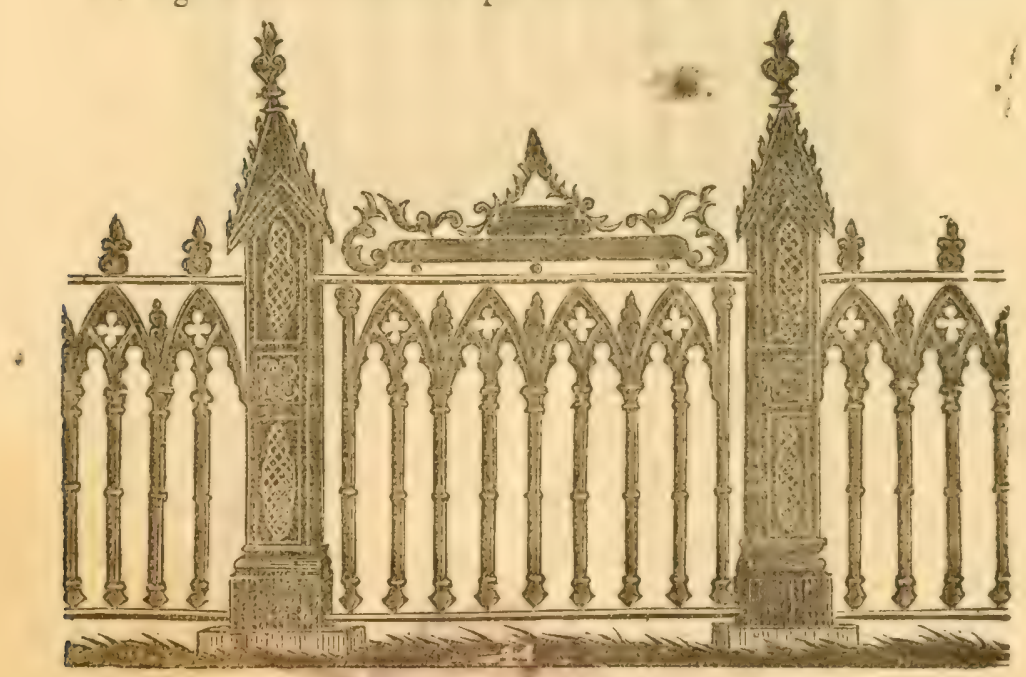




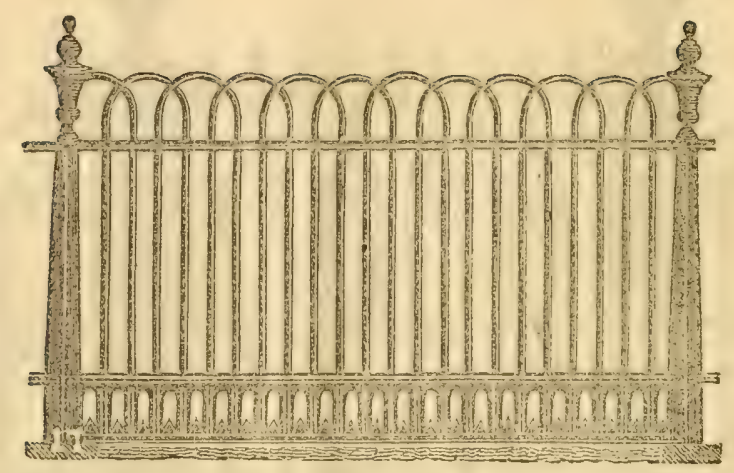

No. 17 represents a pannel of fence with cast iron base and posts. with wrought iron bars and banisters, and is afforded for 40 cents to $\$ 1,50$ per foot.

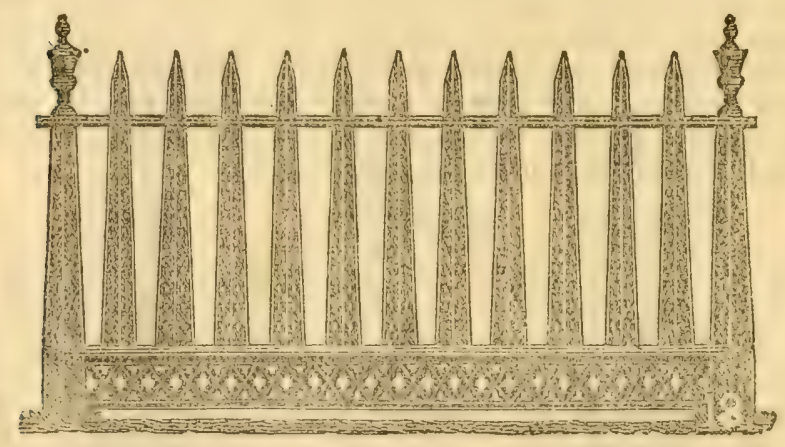

No. 18 represents a pannel of cast iron rail and banister fence, and is sold at $\$ 1$ to $\$ 5$ per foot. 
Reurans. - There are a large vuricty of dimerent styles and designs of fence manufactured at the T. S. Patent Fence Torks, which are not described. It is intender that all clasees and descriptions of fence, and railing of all heights, styles, designs and configuration, shall be manufactured and divered at these works as cheap, as dumble, and as beautiful, as at any other establishnent in the United States or the workl. In addition to the above, all rarieties of rerandahs, aivies, balconies, hatustrales, \&(., \&e,-also, door-grates, window-gruards and shutter-grates, counting-house lsanisters, \&c., together with coal-grates of every size desired.

Also, all clisses of ornamental gates sund gate-ways, both of cast. and wrought iron. Also, cheap aml permanent wronght iron farm gates and cast iron gate-posts, of all styles and varieties.

These works are conducted under the immediate supervision ant care of the Patentee, MIr. MI. P. Conns, lyy the aid of complent amd skillful mechanics; and all orders directed to him, or to the undersigned, proprietor of the works, will be promptly answered.

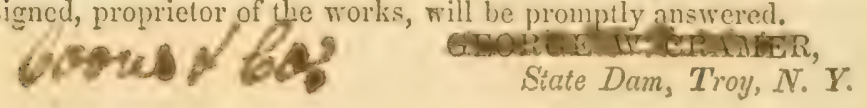




\section{COLEMAN'S}
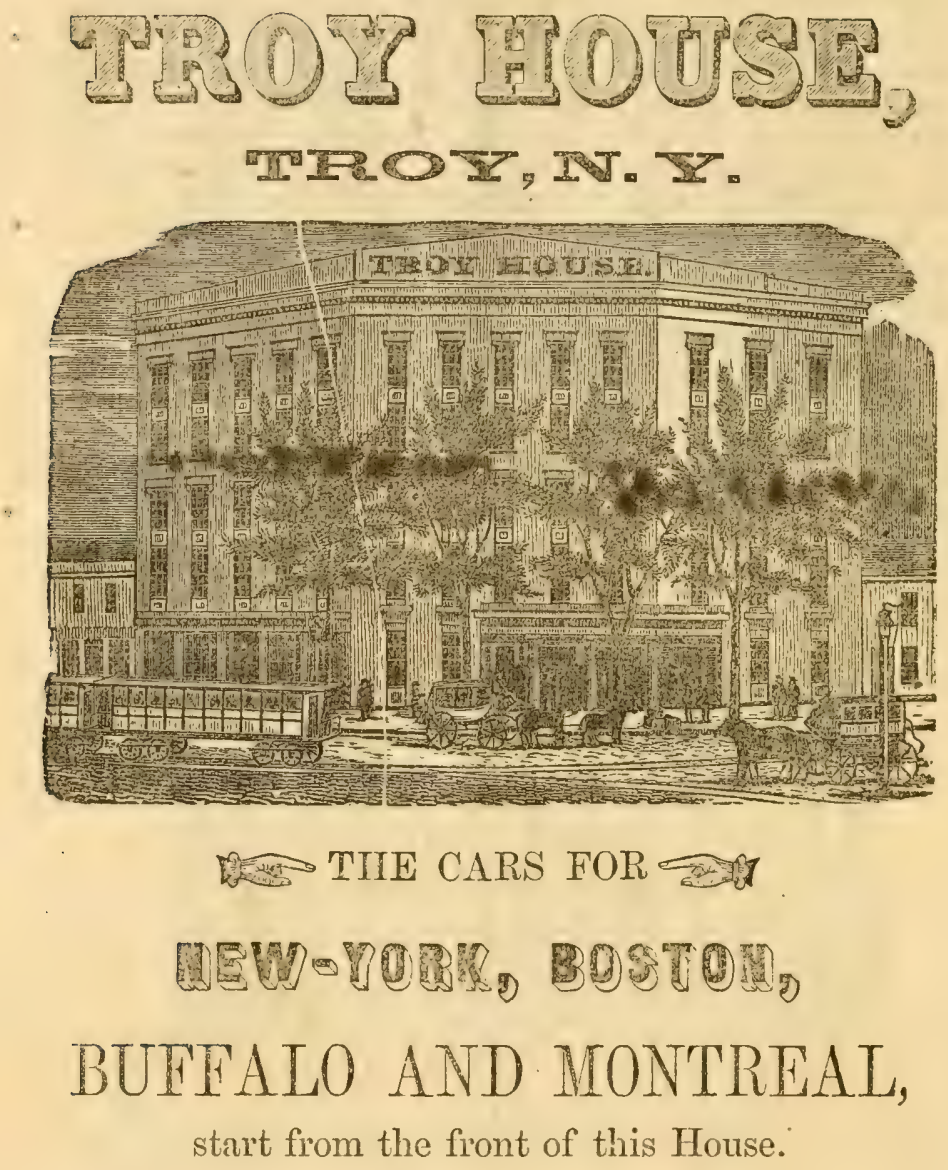

It is also but a few steps, to the right, after leaving the Steam-boat Ianding,

C. S. COLEMAN, Proprietor. 


\title{
Z. W E L LS,
}

\section{MAOITIVIS ST",}

\author{
505 RIVER-STREET,
}

ABOVE IIOOSIC, TROY, N. Y.,

WHEIE ME BLIIUS TO ORDER, TIE ORDMARE

\author{
KINDS OF
}

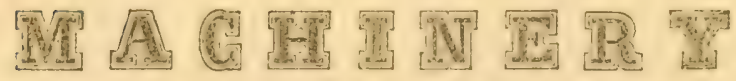

IN USE,-SUCH AS

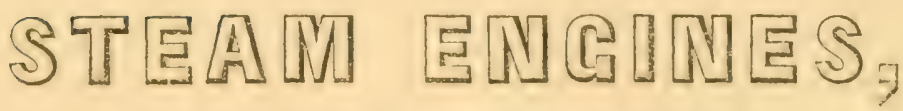

䜿

S A W MILLS,

PLANEING MACHINES,

OTIROUIAIR SA NTS;

ded., de 


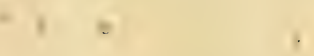

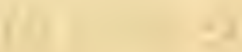




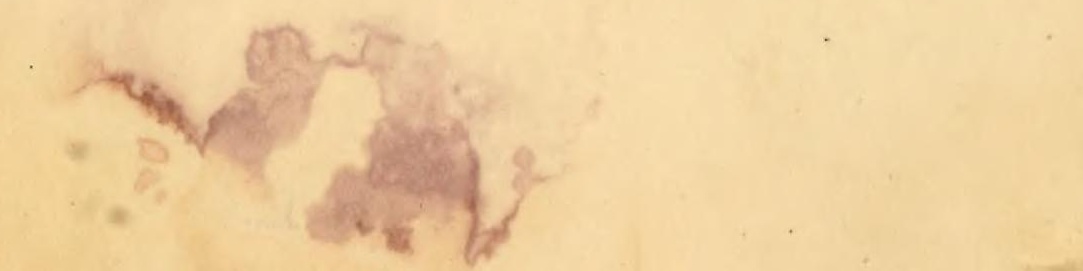



LIBRARY OF CONGRESS

||||||||| |||||||||||||||||||||||||||||||||||||||| 